\title{
Developing the Narrative Risk Disclosure Measurement
}

\author{
Awad Ibrahim* \\ Senior Lecturer \\ Portsmouth Business School; United Kingdom \\ Email: awad.ibrahim@port.ac.uk \\ Khaled Hussainey \\ Professor of Accounting \\ Portsmouth Business School; United Kingdom \\ Email: Khaled.hussainey@port.ac.uk
}

Purpose- This study adopts the pre-modern view of risk as losses only and proposes a new definition of corporate risk disclosure. The new definition is used to formulate new risk-related keywords to develop the process of measuring the risk disclosure score.

Design/methodology/approach- The theoretical part of this study reviews the different methods of measuring narrative disclosure in literature, discusses five arguments on why risk should be defined as losses only, and proposes a new definition of risk disclosure. The empirical part conducts two tests on a sample of 150 annual reports of UK firms during 20052015, formulates new keywords lists, measures RD score from different perspectives, and run correlation and regression analyses for 328 non-financial FTSE All-Share listed firms during 2005-2016, the effect of RD was examined on cost of debt and market firm value one year ahead.

Findings- The first empirical test shows that about $94 \%$ of risk information in annual reports is talking about risk from a negative perspective and negative outcomes only. The second test shows that $87 \%$ of the risk-related sentences in the annual reports discussing risks using negative keywords. The descriptive statistics show that the risk disclosure level is increasing across years during 2005-2015 and the utilities industry reports the highest level. The study concludes that the pre-modern view of risk should be adopted.

Originality/value- This study contributes to the ongoing debate on the risk definition and whether the positive outcomes of events should be included in the risk disclosure definition. Moreover, the study proposes a new definition of risk disclosure and provides theoretical and empirical evidence on why the pre-modern view of risk should be adopted. Moreover, new risk-related keywords are used for the first time in the risk disclosure literature.

Keywords: Risk; Risk Disclosure; QSR; Annual Report; UK 


\section{Introduction}

Corporate financial reporting is the accounting product that facilitates communication between managers and all stakeholders. Investigating the determinants and value-relevance of the financial reporting and its different categories is one of the most important research topics in financial accounting. Investigating the determinants of disclosure, especially that is provided on a voluntary basis, could help in understanding the drivers of disclosure quantity and quality, while investigating the disclosure value-relevance helps to recognize its gains and economic feasibility compared with its costs. However, measuring the disclosure quantity and quality is a basic step in disclosure studies.

The narrative disclosure measurement is a critical issue in the disclosure literature that is conducted by several and different methods. Some researchers measure narrative disclosure by counting the number of relevant words or sentences (e.g., Linsley \& Shrives, 2006; Rajab, 2009; Dobler et al, 2011; Ntim et al, 2013; Elshandidy et al, 2013; Mokhtar \& Mellett, 2013), while others constructed an index to measure the disclosure level (e.g., Botosan, 1997; Mokhtar \& Mellett, 2013; Lipunga, 2014). A few researchers used a dummy variable such as Iatridis (2008) and El-Gazzar et al. (2011). Moreover, authors found to depend on ready ratings of disclosure as proxies for disclosure quantity or quality, such as Welker (1995), Healy et al. (1999), and Gelb and Zarowin (2002), while a few found to used surveys and interviews, such as Frolov (2006) and Tauringana \& Chithambo (2016). However, counting the number of sentences seems to be the most common method. In measuring Risk Disclosure (RD) level, most RD studies found to prepare lists of keywords that express any kind of risk then use these keywords to count the number of risk-related sentences, such as Linsley \& Shrives (2006), Abraham \& Cox (2007), Linsley \& Lawrence (2007), Greco (2012), and Ntim et al. (2013).

This study aims to develop the measurement of the narrative RD for two reasons. First, the sensitivity and importance of risk information. Second, the ongoing debate on the definition of risk and whether the positive outcomes should be included in the risk definition. The study argues that RD could be very important compared with other reporting categories. Risk information is important since it discusses the present and potential risks and uncertainties that could threaten the continuity of business. Moreover, RD could have important investment, financing, and liquidity implications by reducing agency and information asymmetry problems (Abraham and Cox, 2007; Ntim et al. 2013). Campbell et al. (2014) find that higher RD level is negatively associated with information asymmetry and stock return volatility. 
On the other hand, the value-relevance of RD is recognized and promoted by different accounting boards and bodies, such as Institute of Chartered Accountants in England and Wales (ICAEW) in the UK, the International Integrated Reporting Council (the IIRC), and German Accounting Standard Board (GASB) in Germany. ICAEW issued a series of reports that encourage managers to develop corporate reporting, especially the corporate $\mathrm{RD}$, starting from ICAEW 1997 report to the most recent report; ICAEW (2017) "What's next for corporate reporting: time to decide? Moreover, the IIRC (2013) states that an Integrated Report should include eight content elements including risks and opportunities, whereby company should report on what are the specific risks and opportunities that affect their ability to create value and how they deal with them? In addition, the German Accounting Standard Board (GASB) issued GAS 5 "Risk Reporting in Germany in 2001, which is considered the first comprehensive risk reporting standard around the world. On the literature level, the importance of RD was examined several years ago. For example, Solomon et al. (2000) is one of the early studies that tried to present a conceptual framework for corporate RD and examine the attitudes of investors towards risk information in the UK. The study provides empirical evidence that institutional investors admit that higher RD level would help in making the portfolio investment decisions.

Before measuring RD, it is important to define "risk information" precisely, and before that we should identify what we mean by the word "risk". The risk has been defined in the literature from different perspectives. The literature provides the one-side view, the two-side view, and the variation view of the word "Risk" (Linsley \& Shrives, 2006; Abraham \& Cox, 2007; Elshandidy, 2011). Whether to include the positive outcomes into the risk definition is debatable in the RD literature. Accordingly, this study discusses this debate and presents its own definition of RD.

This study contributes to the ongoing debate on the definition of risk information as follows. First, the study presents five theoretical arguments on why RD should be defined from the negative side only. Second, the study conducts two empirical tests that confirm these arguments. Third, the study proposes a new definition of RD that is consistent with the premodern definition of risk that should be adopted by researchers. Fourth, the study generates new risk-related keywords to be used to measure RD level and are consistent with the proposed definition and the pre-modern view of risk.

The remainder of this study proceeds as follows. Section two reviews the narrative disclosure measurement in literature. Section three discusses the different concepts of risk and RD definitions. Section four discusses five theoretical arguments on why RD should be defined 
from the loss side only. Section five presents two empirical tests that support the study view of $\mathrm{RD}$ and presents a new definition of RD. Section six presents keywords lists to measure RD while section seven presents the descriptive statistics of RD scores across years and industries and in total. Finally, section eight discusses the validity tests and the study implications while section nine concludes.

\section{A Review of Narrative Disclosure Measurement}

Hassan \& Marston (2010) classify the approaches of measuring narrative disclosure into two main approaches. The first approach examines disclosure by directly inspecting the disclosure means, such as annual reports. This includes counting the disclosure, constructing indices, and using dummy variables. For example, Linsley \& Shrives (2006), Hill \& Short (2009), Elzahar \& Hussainey (2012), Miihkinen (2012), Ntim et al. (2013), and Marzouk (2016) applied the content analysis to measure the RD directly by inspecting its level and attributes in annual reports. The second approach inspects indirectly the corporate disclosure without returning to the original disclosure means, such as conducting disclosure surveys and interviews with market participants to collect references about disclosure and their perceptions, such as surveys as conducted by Frolov (2006). Figure (1) shows six direct and indirect methods and two main techniques used in literature to measure disclosure.

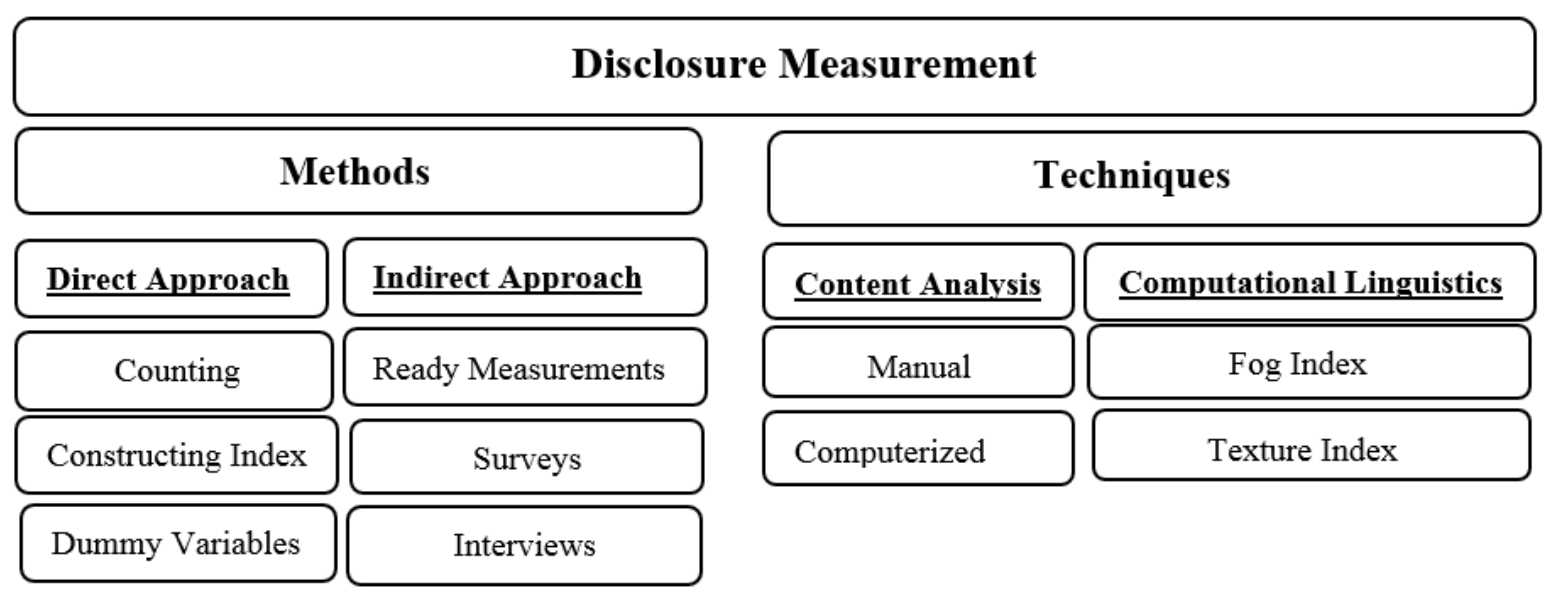

Fig. (1): Methods \& Techniques of Disclosure Measurement

\subsection{Counting the Narrative Disclosure}

Counting is a direct method of measuring the narrative disclosure. Although it seems a primitive method, it is effective when measuring the quantity rather than the quality. The disclosure level is measured simply by counting the risk-related words or sentences before 
transforming this number into a natural logarithm. Many studies such as Linsley \& Shrives (2006), Abraham \& Cox (2007), Hill \& Short (2009), Elzahar \& Hussainey (2012), Miihkinen (2012), and Ntim et al. (2013) found to follow this method.

The coding (measurement) unit may be a word, sentence, paragraph, a part of page, or the whole page. According to Helbok \& Wanger (2006), Copeland \& Fredericks (1968) introduced counting the disclosure using the word as a measurement unit. However, the word as a measurement unit is criticized since the word meaning relies on its syntactical role within the sentence and the word by itself does not convey a meaning (Milne \& Adler, 1999; Linsley \& Shrives, 2006; Hassan \& Martson, 2010). Moreover, using insufficient or improper words could over- or underestimate the counted disclosure level (Hassan \& Martson, 2010). Moreover, Moumen et al. (2015) argue that risk-related words cannot be categorized into different risk categories before reviewing the sentence. Some studies found to use the word as a measurement unit such as Miihkinen (2012), Campbell et al. (2014), and Filzen (2015).

On the other hand, Milne \& Adler (1999) and Linsley et al (2006) argue that measuring RD level using sentences rather than words or pages is a more reliable coding method. Elshandidy \& Neri (2015) argue that using the sentence as a coding unit in the content analysis is more reliable because words may not imply any meaning individually. Further, Kravet \& Muslu (2013) argue that using the sentence as a coding unit helps to void double-counting, as if the sentence contains several risk-related words, it is scored once. Milne \& Adler (1999) argue that sentences as measurement units provide meaningful, complete and reliable data. Finally, although counting is a direct method to measure disclosure, it may not be effective in evaluating the quality of disclosure. Moreover, this method is time-consuming and requires an amplified effort, unless the computerized content analysis is employed.

\subsection{Constructing an Index}

Another direct method to measure the disclosure is by constructing a disclosure index through three steps. First, the authors prepare a checklist of certain disclosure items. Researchers usually depend on existing accounting standards or regulations or even prior studies when constructing a checklist of disclosure items. For example, Mokhtar \& Mellett (2013) prepare a mandatory RD checklist based on the Egyptian Accounting Standard 25 “Financial Instruments: Presentation \& Disclosure". Lipunga (2014) constructs RD index and disclosure checklist of 6 risk groups that are constructed according to Pillar 3 of Basel 2 Accord. Moreover, Atanasovski (2015) depends on the requirements of IFRS 7 to construct RD checklist, while Habbash et al. (2016) construct a checklist of voluntary disclosure items 
depending on studies of Meek et al. (1995) \& Botosan (1997). Second, the authors examine whether each checklist item is disclosed or not in the disclosure report following a certain coding scheme. Beattie et al. (2004) state two coding schemes, the simple binary method whereby the existence or absence of a disclosure item is investigated and values of one and zero are used, while the ordinal coding scheme could incorporate more than two values, like the three levels coding scheme used by Botosan (1997). Third, authors sum the scores given to each firm-year observation, and then divide this score by the maximum index score to represent the level of actual disclosure and the value of disclosure index. Some studies have used more than one index to measure RD from different perspectives. For example, Beretta \& Bozzolan (2004) used four indices to measure RD; the first measures RD as the standardized residuals of a regression model, the density index measures $\mathrm{RD}$ as the ratio of risk-related sentences to the total number of sentences, the depth index measures RD based on the sign of the economic impact, while the fourth index measures RD based on the extent to which the companies disclose information on actions taken to face the potential risks.

Overall, this direct method to measure disclosure is very effective, especially if the objective is to examine the compliance with disclosure regulations, where the checklist could contain the disclosure items as imposed by the disclosure standard or regulation, and researchers can examine to what extent these items are disclosed by the sample companies. Moreover, to be a good indicator of disclosure level, the items included in the checklist should be adequate and cover the different aspects of disclosure under investigation.

However, this method has some limitations. First, it should be emphasized that scores of the disclosure indices are not necessarily measures of disclosure quality. Second, using selfconstructed indices to measure disclosure is very labour-intensive, subjective, expensive, and feasible only for small samples (Core, 2001; Beyer et al. 2010; Berger, 2011). Botosan (1997), Linsley \& Shrives (2006), and Abraham \& Cox (2007) argue that using a disclosure index requires subjective assessments. To minimize the potential subjectivity, authors follow certain tests to confirm the validity and reliability of their results, such as involving an additional independent person to read, code and evaluate the examined document. Using the computerized content analysis may alleviate some of these limitations. Several authors such as Hussainey et al. (2003), Kothari et al. (2009), Gruning (2011), Elshandidy et al. (2013), Elshandidy et al. (2014), and Elshandidy and Neri (2015) apply the computerized content analysis. 


\subsection{Dummy Variable}

Using a dummy variable is another method to differentiate between disclosers and nondisclosers or providers of high-quality disclosure and those of low-quality disclosure. Iatridis (2008) used a dummy variable that is devoted to one if a company is a provider of high-quality information and zero if it is a provider of low-quality information. El-Gazzar et al. (2011) used a dummy variable that equals one if a company found to report on the weaknesses of internal control and zero otherwise. However, Sun (2015) depended on the auditor opinion, where the disclosure variable equals one if the auditor opinion on internal control was adverse and zero otherwise. It sounds that this method is not empirical and does not provide an in-depth understanding of disclosure quantity, quality, and attributes; just it helps to differentiate between disclosers and non-disclosers. Moreover, it is not popular in the disclosure literature.

\subsection{Ready Disclosure Measurements}

Some authors found to direct to ready measurements of disclosure published by professional or academic bodies, or even prepared by prior studies. For example, the Association of Investment, Management and Research (AIMR) in the USA used to provide ratings of disclosure, known as AIMR ratings, to encourage and improve corporate disclosure (Healy et al. 1999; Healy \& Palepu, 2001; Beattie et al. 2004; Hassan \& Martson, 2010). Authors found to depend on these ready ratings of disclosure as proxies for disclosure quantity or quality, such as Welker (1995), Healy et al. (1999), and Gelb and Zarowin (2002). However, the AIMR disclosure ratings were discontinued in 1997 (Core, 2001; Beyer et al. 2010; Berger, 2011). Other examples of ready disclosure measurements are the Standard and Poor's Transparency and Disclosure Scores and the SEC Ratings of the Management Discussion and Analysis Disclosure (Hassan \& Martson, 2010). Moreover, some databases such as DataStream and Bloomberg provide researchers with prepared scores for certain types of disclosure such as Environmental Disclosure (Field, RX374), Social Disclosure (Field, RX375), and Governance disclosure (Field, RX376).

\subsection{Surveys \& Interviews}

Conducting surveys or interviews is another indirect method to recognize the disclosure level and attributes. Basel Committee conducted three surveys in 1999, 2000, and 2001 across 13 countries to examine the RD practices in the banking industry. Further, Frolov (2006) conducted a survey in Japan to examine the RD practices in a sample of banks and credit institutions. Riley \& Taylor (2015) depend on the experiment and online survey to evaluate the 
readability of disclosure on three risk factors. Tauringana \& Chithambo (2016) conducted four personal interviews with four company managers. Further, Linsley \& Shrives (2005), and Greco (2012) recommend conducting interviews with companies' directors and market participants to investigate the state of disclosure and to what extent it is value-relevant.

Although using surveys and interviews may be an easy method to measure disclosure than constructing labour-intensive disclosure indices, the disclosure measurement quality using these methods depends mainly on the quality of conducting the interviews and formulating the questions of surveys and to what extent the views of the interviewees are objective (Hassan \& Martson, 2010). Moreover, despite the simplicity of this method, it is not popular, after reviewing the literature, only one study found to conduct interviews (Tauringana \& Chithambo, 2016) and one found to conduct a survey (Frolov, 2006).

\subsection{Techniques of Narrative Disclosure Measurement}

The literature provides two main techniques to examine the disclosure narratives and measure the disclosure level: the content analysis and computational linguistics. The content analysis is the most common technique used to measure disclosure and may be the most valid and reliable technique (Linsley \& Shrives, 2006; Abraham \& Cox, 2007; Elzahar and Hussainey, 2012; Kothari et al. 2009; Elshandidy et al. 2013; 2015). Moreover, Krippendorff (2013) argues that content analysis ensures repeatability and valid references from the narratives. Furthermore, Gray \& Haslam (1990) argue that content analysis is a valid and reliable means for measuring the disclosure, since it evaluates the disclosure without the knowledge of information providers.

The content analysis could be manual or computerized. The manual content analysis counts the disclosure level manually; however, this technique requires considerable effort and time and increases the measurement error. Some studies such as Linsley \& Shrives (2006), Abraham \& Cox (2007), Deumes (2008), Greco (2012), Elzahar \& Hussainey (2012) and Elzahar et al. (2015) used the manual content analysis. On the other hand, the trend of using the computerized content analysis has increased during recent years due to the advances in computer technology. Another set of studies followed the computerized content analysis, such as Woods \& Marginson (2004), Kothari et al. (2009), Gruning (2011), Ntim et al. (2013), Elshandidy et al. (2013), Elshandidy et al. (2015), Elshandidy \& Neri (2015) and Hassanein (2015). The computerized content analysis is less subjective, and less time-consuming compared with the manual content analysis. 
On the other hand, a set of studies recommends importing techniques of natural language processing from linguistics and artificial intelligence and incorporates in disclosure measurements, such as Core (2001), Beyer et al. (2010) and Berger (2011). Berger (2011, p. 216) state, "Natural language processing techniques represent one innovative way to capture broad aspects of disclosure and aspects of disclosure not readily measured by other means". Furthermore, Beyer et al. (2010, p. 312) state" ..., we believe that analyzing disclosures using natural language processing techniques seems most promising in creating meaningful disclosure quality measures for large samples". However, despite the recent innovations in the computational linguistics, most disclosure researchers found to depend mainly on the content analysis and avoid using such advanced techniques. This may be due to the lack of experience of accounting researchers by the techniques of artificial intelligence and linguistics. However, future researchers can develop the disclosure measurement by involving specialists of linguistics in their empirical research.

Based on this review, this study contributes by developing the RD measurement using the counting method and new keywords after discussing the risk concepts and the RD definitions and introducing a new definition of $R D$.

\section{Risk Concepts and RD Definitions}

To determine whether a certain sentence or paragraph is a risk disclosure or not, it is important to recognize and define the risk meaning first. The concept of risk has developed from covering only the negative outcomes of events to covering both the negative and positive outcomes. The literature provides several concepts of risk that can be classified into one-side definitions and two-side definitions. For example, Lupton (1999) identifies risk as a hazard, threat, or harm, while Horcher (2005) defines risk as the possibility of loss. These authors recognize the risk as a loss or uncertainty with negative outcomes. Some disclosure regulations define risk as loss as well. For example, the SEC defines risk in FRR No. 48 in terms of loss (Hodder et al. 2001). German Accounting Standard (GAS 5) defines risk as the possibility of a negative influence on the economic position of the firm (Elshandidy et al. 2015).

However, the risk may carry the potential of either gain or loss (Schrand and Elliott, 1998; Solomon et al. 2000; Hodder et al. 2001; Mokhtar \& Mellett, 2013) and therefore, it should be defined to cover the positive and negative prospects. Linsley \& Shrives (2006) state that the modern view of risk incorporates both the negative and positive outcomes of events. Moreover, the ICAEW (2002) report "No Surprises: working for better risk reporting” states that risks have a range of different outcomes that could be upside or downside and therefore the institute 
views that RD should cover business risks, threats, and opportunities as well. Furthermore, according to the international risk management standard (ISO 31000:2009), risk is defined as the influence of uncertainty on the firms' objectives that could be positive or negative. Moreover, FRS 5 defines risk as the uncertainty as to the amount of benefits. Practically, Abraham \& Cox (2007) use risk in three contexts: risk as variation, risk as uncertainty, and risk as an opportunity. They use advantage, upside, prospect and potential as synonyms for risk as an opportunity. Hodder et al. (2001) consider both loss and probability in defining risk and consider dread, unknown and gains as three secondary factors of risk. Furthermore, Elshandidy et al. (2015) apply a definition for risk that includes both the potential gains or opportunities and potential losses. One of the early studies, Solomon et al. (2000, p. 449), defines the risk according to the modern view as "Risk may be defined as the uncertainty associated with both a potential gain or loss".

However, the risk could be defined also as a variation. Abraham \& Cox (2007) and Elshandidy (2011) examined the risk as a variation. Elshandidy (2011, p.34), state “..., risk can be defined as the variations or fluctuations around a target value at a specific time horizon". Elshandidy (2011) states that he adopted this definition to avoid the debate on the risk definition. Moreover, Abraham \& Cox (2007) examine the risk as a variation, uncertainty, and opportunity. This found to be consistent with the International Financial Reporting Standard (IFRS 4) - "Insurance contracts" that defines the financial risk as:

\footnotetext{
"The risk of a possible future change in one or more of a specified interest rate, financial instrument price, commodity price, foreign exchange rate, index of prices rate, credit rating or credit index or other variable, ..."
}

However, it is apparent from the literature review that when researchers examine RD, they consider the negative side of risk more than the positive one or a variation. This is consistent with the assumption of the prospect theory that people react to losses more severely than their reaction to gains (Hodder et al. 2001). Researchers seem to recognize and examine RD as dissemination of threats and dangers that face the firms rather than viewing some risks as opportunities. The ICAEW (2011) report “Reporting Business Risks" states that most RD practices focus on the risk in the negative sense and that people understand risk as the possibility of incurring losses or reduced profits or something else disadvantageous. The report (P. 3) state, "Most risk reporting in practice is about risk in the negative sense...".

In defining RD, Linsley \& Shrives (2006, p. 389) provide a comprehensive definition of RD that covers both the positive and negative views of risks and states several synonyms of risk: 
"...disclosures have been judged to be risk disclosure if the reader is informed of any opportunity or prospect or of any hazard, danger, hard, threat or exposure that has already impacted upon the company or may impact upon the company in the future or of the management of any such opportunity, prospect, hazard, harm, threat or exposure."

It is evident that this definition starts with the positive dimension by stating opportunity and prospect then follow to the negative dimension of risks. The definition states several synonyms of risk that makes it easy for RD researchers to use it as a guide in defining and measuring the quantity and the quality of RD. Subsequently, a large set of studies found to follow Linsley \& Shrives (2006) and adopt their broader definition of risk, such as Rajab \& Handley-Schachler (2009), Dobler et al. (2011), Elzahar \& Hussainey (2012), Mokhtar \& Mellett (2013), Ntim et al. (2013), Al-Shammari (2014), and Moumen et al. (2015).

Furthermore, Hassan (2009, p. 669) provides a broader and general definition of RD:

“....as the financial statements inclusion of information about managers' estimate, judgments, reliance on market-based accounting policies such as impairment, derivative hedging, financial instruments, and fair value as well as the disclosure of concentrated operations, non-financial information about corporations' plans, recruiting strategy, and other operational, economic, political and financial risks".

Hassan (2009) argues that his definition of RD coincides with several researchers' definitions of RD and communicates both the "good" and "bad" information and reporting on uncertainties. However, this definition is so general and does not determine the different synonyms of risks, compared with that provided by (Linsley \& Shrives, 2006).

In total, the pre-modern view recognizes "risk" as something bad (negative outcomes), and the modernist view recognizes "risk" as both the negative and positive outcomes of events. Whether to include gains and positive outcomes into the risk definition is still debatable in the $R D$ literature. Nevertheless, this study adopts the risk definition as a loss and proposes a new definition of RD that includes the negative outcomes only rather than both the positives and negatives. However, to justify this novel move in the RD literature, the study provides two pieces of evidence: theoretical and empirical evidence. The theoretical evidence consists of five theoretical arguments on why risks should be examined as negative outcomes only, and the empirical evidence is presented through testing how risk is defined and expressed in a sample of UK annual reports. 


\section{A Theoretical Evidence}

This study adopts the pre-modern view of risk as a loss and measures the RD as negative outcomes only. This view is based on five theoretical arguments that justify why risk information should be examined as negative outcomes only.

Firstly, advanced RD regulations found to concentrate on the negative risk information disclosure, such as those of SEC in the USA, the German Accounting Standard (GAS 5), and Basel Committee risk regulations in the banking industry. For example, FRR No. 48 is one of the advanced RD regulations that issued in the USA in 1997. FRR No. 48 concentrates on disclosure of negative risks only (Hodder et al. 2001; Elshandidy, 2011). Hodder et al. (2001) state that FRR No.48 requires that managers disclose market risk information for risks of loss arising from adverse changes in interest rate, foreign currency rate, commodity prices, and equity prices. The subsequent updates of the SEC in December 2005 require firms to describe the most significant risk factors that may adversely affect the firms' business (Filzen, 2015). The SEC (2005, p. 260) regarding risk factors disclosure states, “...the risk factors disclosure would have required a discussion of the most significant factors with respect to the registrant's business, operations, industry, or financial position that may have a negative impact on the registrant's future financial performance". Furthermore, Filzen (2015) states that the SEC 2005 regulations impose penalties on firms that fail to disclose on the negative economic events.

Furthermore, the only extant comprehensive accounting standard of risk reporting (GAS 5) in Germany found to concentrate on the negative side of risk. GAS No. 5 defines the risk as "the possibility of future negative impact on the economic position of a firm" (Elshandidy, 2011). On the other hand, in the banking industry, the Basel committee issued several regulations to organize risk management and disclosure in banks. These regulations found to define the risk as a loss, such as Pillar (3) of Basel 2 Accord (2004; 2015), where the Basel Committee on Banking Supervision (2004, p. 149) defines the operational risk as "Operational risk is defined as the risk of loss resulting from inadequate or failed internal processes, people and systems or from external events". On the other hand, some guidelines on risk management and reporting found to differentiate between risk and opportunity and use the two keywords as carrying different meanings, such as the FRC (2014)'s report on risk management and reporting and the IIRC (2013)'s report of Integrated Reporting Framework.

Secondly, the definitions of the word "Risk" in different dictionaries and the definitions of different types of business risks are found to describe the negative side only. For example, the Concise Oxford Dictionary (2009) defines the risk as chance of hazard, bad consequences, loss or exposure to danger (Elshandidy, 2011). The Free Dictionary defines "Risk" as "The 
possibility of suffering harm or loss". The Cambridge Dictionary defines "Risk" as "The possibility of something bad happening". The German Duden dictionary defines the "Risk" as a possible negative outcome for a company or a project, which is associated with disadvantages, losses, and damages (Elshandidy, 2011). Moreover, Hodder et al. (2001) argue that much of existing psychology literature defines the risk as a loss. Finally, Kaplan \& Garrick (1981) and Adams (2009) define the risk as negative outcomes.

Thirdly, when searching for the definitions of a specific type of risk, such as operation risk or financial risk, the definitions found to mention the risk as a loss rather than a gain or opportunity. For example, Basel Committee on Banking Supervision (2004, p. 149) defines the operational risk as "Operational risk is defined as the risk of loss resulting from inadequate or failed internal processes, people and systems or from external events". Ntim et al. (2013, p.3) define financial risk as possible losses in the financial markets. Business risk is also defined as the possible losses that arise from the competitive skills that firms have and credit and liquidity risks that arise from failing to meet and discharge an obligation (Elshandidy, 2011). The default risk is defined in many places as the probability of being unable to repay the debt obligations. The business dictionary defines the environmental risk as "Actual or potential threat of adverse effects...". This indicates that the risk is defined socially and traditionally as negatives.

Fourthly, the studies that adopt the two-side definitions found to depend on negative keywords more than positive keywords. For example, Elshandidy \& Neri (2015) used a list of 26 risk keywords before derivatives, only 6 words of this list are positive (chance, gain, high, increase, peak, viable). Moreover, Linsley \& Shrives (2006) used 7 main keywords, only two could be positive (opportunity and prospect). Likewise, Abraham \& Cox (2007) used 15 words before derivatives, only five of them are positive (opportunity, prospect, potential, upside, and advantage). This implies that when researchers adopt the two-side definition of risk, the counting of the risk-related sentences is biased toward the negative risk.

Finally, the users of financial reports are more likely to search for losses and threats when they are reading the risk sections. They usually understand risk in the negative sense of a possibility of incurring losses or reduced profits (ICAEW, 2011). Users do not expect to find information on opportunities or gains when managers disseminate any risk information. The prospect theory assumes that people react to losses more severely than their reaction to gains (Hodder et al. 2001). Users may become upset when finding many positive words inside a risk report or it could be understood as impression management. Not only the users of financial reporting expect risk information to be on losses, but also the preparers of such information are 
more likely to concentrate on the negative side. ICAEW (2011) states that most risk information in practice is about risks on the negative side.

\section{Empirical Evidence}

Two tests have been conducted to examine a sample of UK annual reports to find out how "risk" is expressed in the annual reports' narratives, whether as negative outcomes only or as both negative and positive outcomes.

\subsection{The First Test}

Firstly, 3,608 annual reports have been collected for 328 non-financial firms listed on FTSE All-Share during 2005-2015. These reports were collected in PDF format from both Bloomberg and the websites of the firms. A sample of 150 annual reports was randomly selected and converted into Text Files. The randomly selected annual reports represent all the 9 industries excluding the financial firms' industry according to the ICB industry classification. Also, only one report was selected for one company so more companies would be represented in the sample. Then, these Text Files were imported into QSR software. Next, I searched for the keyword "Risk" and did not tick the option "Whole word or Phrase only" to collect its derivatives, such as "Risky" and "Risks". The resulting file brings 7,723 risk-related sentences. Next, I randomly selected 100 sentences, which are listed in Table (1). Then, I with my coauthor (Hussainey, 2004) read all these sentences individually to differentiate them based on their orientation whether loss or gain and loss. The 100 sentences are ranked into two Panels as shown in Table (1).

Panel (A) of the table shows the sentences that discuss the risk as a loss, while Panel (B) shows the sentences that discuss the risk as both loss and gain and others that we could not determine their tendency, because they are too general risk-sentences. The results show that 90 sentences out of 100 discuss the risk as a loss, while 6 sentences found to reveal negative and positive outcomes together, and 4 unclear sentences are too general to determine their tendency. If the unclear sentences are excluded, then the remaining sentences are 96. The ratio of sentences discussing risk as a loss is $93.75 \%(90 / 96)$ or $90 \%$ of the total sentences (90/100). This test provides empirical evidence that the preparers of annual reports when writing about risk information; they are more likely to express the risk information as negative outcomes only, which is consistent with the pre-modern view of "risk" as a loss only. 


\subsection{The Second Test}

The first test brings a text file of 7,723 risk-related sentences. To conduct the second test, this file is imported into QSR. Then, the negative and positive keywords used in literature are searched for, such as Linsley \& Shrives (2006), Abraham \& Cox (2007), Elshandidy et al. (2013 \& 2015), and Elshandidy \& Neri (2015). This test helps count the number of sentences that include negative keywords and the number of sentences that include positive keywords out of the 7,723 risk-related sentences. Table (2) shows the examined keywords and their frequency. To balance the comparison, 10 negative keywords are compared with 10 positive keywords.

The results indicate that the total frequency is 2,804 , where the positive risk keywords are repeated 364 times with a percentage of $13 \%$ of the total number, while the negative risk keywords included in the risk-related sentences are repeated 2,440 times, with a percentage of $87 \%$ of the total number. This result indicates that $87 \%$ of the risk-related sentences of the sample of 7,723 sentences discuss the risk as negative outcomes. This empirical evidence supports the result found in the first test, where $90 \%$ of the risk-related sentences found to discuss the risks as negative outcomes. Even after adding the 4 excluded keywords (unable, danger, shock, shortage), the results remain unchangeable.

Accordingly, based on the first and second tests, it can be concluded that the annual reports express risks as negative outcomes more than as positive outcomes, with percentages of $90 \%$ (Table 1) and $87 \%$ (Table 2), respectively. These results assert the study theoretical arguments that risk information should be examined as negative outcomes of events only.

\section{Insert Table (2) about here}

\subsection{A New Definition of RD}

According to the theoretical arguments and the results of the empirical tests, this study adopts the pre-modern view of risk as a loss only. This is consistent with the SEC regulations (FRR No. 48 and the subsequent updates in 2005 in the USA) that require managers to disclose on market risks as losses only (Hodder et al. 2001; Elshandidy, 2011). This is also consistent with the only comprehensive accounting standard of risk reporting (GAS 5) that defines the risk as negative impacts on the economic position of a firm. The loss definition is also consistent with the risk definition of several English Dictionaries, and consistent with most textbooks and dictionaries that define the different types of risks as negative effects. 
Accordingly, this study introduces a new definition of risk disclosure that expresses risk information as losses only:

"Risk Disclosure can be defined as any information about the past, present, or potential loss, failure, collapse, crisis, deterioration, breakdown, accident, emergency, hazard, danger, harm, threat, or exposure that enables the present and potential users to identify and assess the current and potential negative outcomes for a business"

This definition is consistent with the pre-modern view of the risk as losses only. The definition considers the past, present and future negative outcomes and considers the present and potential users of information. Unlike the definition of Linsley \& Shrives (2006) that includes both negative and positive keywords, this study definition includes negative keywords only. Unlike the definition of risk as a variation as measured by Abraham \& Cox (2007) and Elshandidy (2011), the study definition excludes any keywords that express the risk as variations or fluctuations.

This definition needs to be applied in the study. Therefore, a set of steps are followed to generate a list of keywords that are consistent with the introduced RD definition. A list of new risk-related keywords is generated to measure RD level as a loss only under the symbol $(R D$ Loss). However, the study will also develop lists of keywords that comply with the other definitions of RD. The study will measure RD score based on the two-side definition of risk (RD-LossGain), measure the RD score as a variation (RD-Variation), and as a comprehensive measure (RD-Comprehensive). How to generate these keywords is explained in the following sections.

\section{The Risk Keywords Lists}

To choose the most suitable keywords, two steps are followed. First, an initial list is generated by reviewing the RD literature, the RD regulations and by searching on the synonyms of the existing keywords using the website http://www.thesaurus.com/. Second, a filtering process is conducted to create a final list depending on the frequency of the suggested keywords in the annual reports and whether they are used within the RD context.

\subsection{The RD-Loss List (The one-side definition)}

The one-side definition adopted by this study defines the risk as a loss only and focuses on the negative outcomes of events rather than opportunities, gains, or any variations or 
fluctuations. To generate a list of the risk-related keywords that are consistent with this definition, the next steps are followed.

First, follow a certain risk classification. The risk classification provided by ICAEW (1997) and subsequently used by Linsley \& Shrives (2006) is used. Table (3) shows six risk categories: Financial Risk, Operation Risk, Empowerment Risk, Information Processing \& Technology Risk, Integrity Risk, and Strategic Risk. This step is important to identify the keywords that are more likely to appear when describing each risk category, so that the final list of keywords will ensure a comprehensive and more representative list of all common risk categories.

Second, suggest an initial list of keywords that are more likely to be used within each risk classification. To create this list, several sources discussing the different risk categories are reviewed: (1) examine a sample of 150 randomly selected annual reports using QSR and review all sentences containing the word "Risk", then the negative keywords used within these sentences are collected, (2) examine the keywords mentioned in IFRS 7, the UK Corporate Governance Code (2014; 2018), and the Basel Committee on Banking Supervision (2004) and BCBS (239), (3) review the academic and professional literature, such as Linsley \& Shrives (2006), Abraham \& Cox (2007), and the series of reports issued by ICAEW (1997; 1999; 2002; 2011), and (4) search for the synonyms of the collected risk-related keywords using the website http://www.thesaurus.com/

Third, generate a final list of keywords consistent with the risk definition as a loss. To do so, a filtering process for the suggested keywords is conducted through the next 3 stages:

a. Examine a sample of 150 randomly selected annual reports during 2005-2015 to check the existence and frequency of occurrences of the suggested keywords using QSR and exclude any keywords mentioned in less than 15 sentences. Elshandidy (2011) excluded all the words that did not appear in the search results of a sample of 15 annual reports per country. Hussainey et al. (2003) and Hussainey (2004) excluded any keywords that appeared in less than 30 sentences for a total sample of 60 analysts' reports. Following Elshandidy (2011)'s criterion will bring some keywords that are rarely used to discuss risks and are mentioned once or twice in this study sample of 150 reports, which does not make a sense to include them, such as punishment, dilemma, and cheat. If I followed the criterion of Hussainey et al. (2003) and Hussainey (2004), I would have to exclude keywords mentioned in less than 75 sentences (half the total number of 150 annual reports). However, this found to exclude some key risk words that are common in risk 
reporting, such as danger, harm, bankruptcy, and contingency that are used by literature, such as Linsley \& Shrives (2006) and Abraham \& Cox (2007). In addition, some risk categories would be represented by a few keywords. I found a minimum of 15 sentences is enough, since the keywords mentioned less than 15 times seemed to be uncommon in the financial reporting (Hussainey, 2004), such as blood, radical, war, infection, virus, toxin, conspire, and violence. This first filtering stage brought an initial list of 70 keywords that are mentioned and repeated in 15 sentences or more in the sample of 150 annual reports.

b. However, some keywords found to be inconsistent with the definition of risk as a loss. The keywords "fluctuation", "variation", "volatility", and "change” found to express financial risks, such as fluctuation of interest rates and commodity prices. They are consistent with the risk definition as a variation not as a loss. Therefore, they are excluded to ensure the non-interference between the three lists of keywords, where they will be included in the list of risk definition as variations. Furthermore, the keywords "Risk" and "Uncertainty" are used to express different meanings rather than a loss only. Risk can be negative or positive outcomes or a variation. Therefore, the two keywords are excluded.

c. During the third filtering stage, I used QSR to search for sentences of each keyword individually to ensure that the keywords are used within the context of risk information. I found five keywords used outside the risk-reporting context: "problem", "challenge", "serious", "complex", and "struggle", which are excluded. This final filtering stage brought a final list of 60 keywords.

Finally, following the procedures above generated a new list of 60 risk-related keywords that is considered a major contribution to the RD literature for the following reasons. First, the selected keywords are derived from the actual language and terminology used by the writers of annual reports to disseminate risk information. Second, the selected keywords are derived from the RD regulations (IFRS 7, UK CG Code, Basel Committee) in addition to the relevant academic and professional literature (e.g., Linsley \& Shrives, 2006; ICAEW 1997; 1999; 2002; 2011). Third, the new list is a comprehensive, balanced, and more representative, since it includes keywords that represent six common risk categories, as shown in Table (3). Fourth, the suggested keywords are subjected to three stages filtering process. Finally, the selected risk keywords are consistent with the pre-modern definition of risk as adopted by this study. 


\section{Insert Table (3) about here}

\subsection{The RD-LossGain List (The two-side definition)}

Linsley \& Shrives (2006, p. 389) adopt a broader definition of risk as both negative and positive outcomes. The definition contains both gains and losses but does not include any reference to variation or fluctuation, which makes it different from that adopted by Elshandidy (2011) and his following studies in 2013 and 2015. Linsley \& Shrives (2006, p. 388) state, “..., the modernist view of risk incorporates both the positive and negative outcomes of events". Although the RD definition presented by Linsley \& Shrives (2006) is followed by a large set of studies, such as Rajab \& Handley-Schachler (2009), Dobler et al. (2011), Elzahar \& Hussainey (2012), Ntim et al. (2013), Al-Shammari (2014), and Moumen et al. (2015), none of these studies found to clearly identify the complete keywords lists they used to capture the risk information from the annual reports. Besides, the definition of Linsley \& Shrives (2006) is general and provides an opportunity for its followers to measure RD using different keywords. Accordingly, there is a need to identify precisely the keywords that should be used if the two-side definition of risk is adopted.

This sub-section identifies a list of risk-related keywords that are more likely to express both the negative and positive outcomes using the same steps followed above. Table 4 presents the initial and final lists. The initial list contains 30 positive keywords to represent the risk as positive outcomes. However, the initial list was reduced to only 15 keywords following the same screening criteria followed above. First, any positive keyword mentioned in less than 15 sentences is excluded. Second, six keywords found to be irrelevant are also excluded (outstanding, agree, possible, accept, peak, and viable) because they are used in a different context. Finally, the selected negative keywords are added to the selected positive keywords to generate a final list of 75 of both negative and positive keywords as Table 4 shows.

\section{Insert Table (4) about here}

\subsection{The RD-Variation List (The Variation definition)}

Elshandidy (2011, p. 34) defines the risk as “..., risk can be defined as the variations or fluctuations around a target value at a specific time horizon". He used a final list that includes keywords that express the risk as variations, such as differ, increase, diversify, and fluctuate. 
Afterward, Elshandidy et al. (2013), Elshandidy et al. (2015), and Elshandidy \& Neri (2015) used the same keywords list with new keywords. Moreover, Abraham \& Cox (2007) used the following keywords to express risk as variations: fluctuation, volatility, oscillation, and amplitude. The different market risks, such as exchange rate risk, the commodity risk, and interest rate risk, usually result from variations or fluctuations of the rates and prices. Furthermore, some methods of measuring risk are depending on variation measurements, such as standard deviation and variance (Clarke, 2003) or volatility of returns.

To generate a list of keywords to examine the risk as a variation, the same steps followed above are repeated. Table 5 presents the initial and final lists of the variation keywords. The initial list includes 24 variation keywords. Moreover, 11 keywords that are mentioned in less than 15 sentences are excluded. Additional six keywords are excluded because they are used in a context different from that of RD. These filtering procedures resulted in a final list of 7 keywords.

There are some confusing words, such as "increase", "decrease", and "decline", they can be used to express a positive or negative outcome or to express a variation happened for something. Henry (2008) discusses the problem of "Polysemy", which means that the meaning of the word may differ depending on its context. For example, the word "increase" could be used in the context "expenses increased", which gives a negative outcome, while the word "decrease" could be used in the context "expenses decreased", which gives a positive outcome. Moreover, these words could express a variation as well without causing any confusion. Whatever the context they are used within, they will express a kind of variation for something. Accordingly, the words "increase", "decrease", and "decline" are included in the variation keywords list.

\section{Insert Table (5) about here}

\section{Descriptive Statistics of RD Score}

In this section, the proposed RD definition and the proposed keywords are applied to measure the RD score using QSR software. To measure the score, the annual reports of 328 non-financial firms listed on FTSE All-Share index are collected in a PDF format for the period 2005-2015. The annual reports are collected from the Bloomberg terminal and the firms' websites. Then, these annual reports are converted into Text files and imported into QSR software. Then, a software command is run to measure the RD score based on the inserted keywords. Finally, the descriptive statistics are calculated using SPSS. 
Tables (6) and (7) exhibit the minimum, maximum, mean, median, standard deviation, skewness and kurtosis of the measured RD scores as total and across the study years and across the different industries. As a total, Tables (6) and (7) show that the total number of observations with RD scores is 2,898 out of a total number of firm-years of 3,608 , which indicates that $20 \%$ of the total sample is missing. This may be because some firms are listed on the London Stock Exchange (LSE) after the starting year of the study. For example, Gulf Marine Services PLC was listed on the $19^{\text {th }}$ of March 2014.

Moreover, the total level of RD for RD-Comprehensive is the highest (mean $=356$ in Panel D), followed by RD-LossGain (mean = 225 in Panel B), followed by RD-Loss ( mean $=148$ in Panel A), while the lowest mean (mean = 85) appears in Panel $(\mathrm{C})$ for RD-Variation. These results are expected, since the number of keywords used to measure RD level differs significantly for each measure. The RD-Loss keywords list includes 60 main keywords without derivatives, the RD-LossGain keywords list contains 75 main keywords, the RD-Variation keywords list includes 7 main keywords, while the RD-Comprehensive list includes all keywords included in the prior lists in addition to the keywords "risk and uncertainty", with a total of 84 keywords. Therefore, the mean, minimum, and maximum values of RDComprehensive found to be higher, followed by RD-LossGain, RD-Loss, and RD-Variation. This is apparent also in Figures (2) and (3), where the yellow line (RD-Comprehensive) is the highest, followed by the orange line for RD-LossGain, followed by the blue line for RD-Loss, while the Gray line for RD-Variation comes at the bottom. Finally, the trend of RD level for the four RD scores found to be upward across years as shown in Table (6) and Figure (2), and the utility industry found to report the highest level of RD, while the technology industry found to report the lowest level as shown in Table (7) and Figure (3).

\section{Insert Tables (6) and (7) about here}

\subsection{Descriptive Statistics of RD across the study years}

Table 6 shows the descriptive statistics for the four RD measures across the years. As total, Panel (A) shows that the total mean of RD-Loss score is 148, with a minimum value of 21 and a maximum of 417, indicating that on average the annual report contains 148 risk-related sentences, while there are some annual reports that report up to 417 risk-related sentences and others that report only 21 risk-related sentences. This range implies that there is a large variation between the managers' decisions of the UK firms to disclose any risk-related 
information. Unlike the USA and Germany, the RD is still provided on a voluntary basis in the UK. The trend to provide the RD in the UK on a voluntary basis is one of the main reasons for this variation. However, the range reported by Linsley \& Shrives (2006) for a UK sample is smaller, where the minimum is 20 sentences and the maximum is 275 sentences. In addition, the mean found by Linsley \& Shrives (2006) was 78 sentences, which is much lower than the mean of this study, which is 148 risk-related sentences. However, they examined just one and old year (2000). Moreover, Elzahar \& Hussainey (2012) reported a mean of 28 risk-related sentences, a minimum of 5 sentences and a maximum of 110 , for one year only between 1 June 2009 and 31 May 2010 in a UK sample. Al-Shammari (2014) examined Kuwait as a developing country and reported a mean of 20 sentences in 2012, which is much lower than 78 sentences reported by Linsley \& Shrives (2006), and 148 as reported by this study. In addition, Rajab \& Handley (2009) reported a mean of 93.50 sentences with a minimum of 28 and a maximum of 275 in 52 UK listed firms during 1998, 2001, and 2004. It is normal that the means vary between these studies due to differences in the sample size, the country, the study period, the risk definition adopted, the disclosure measurement method.

Across the years, Table (6) shows that the mean trend of the RD-Loss score is an upward trend, where the mean increases from 96 risk-related sentences in the year 2005 up to 180 riskrelated sentences in the year 2015 , with a percentage of $87.5 \%$. This may back to the awareness increase by the importance of disclosure in general and in RD. Figure (2) shows upward trends not only for RD-Loss, but also for the four different RD measures. Panel (B) of Table (6) exhibits the descriptive statistics for the second RD score (RD-LossGain). The total mean for all study years is 225 with a minimum value of 36 and a maximum value of 607 . This means that there are annual reports that contain up to 607 risk-related sentences based on the second measure of RD and others with a lower number of 36. The mean of RD-LossGain appears to increase gradually from 148 in the year 2005 up to 284 in the year 2015, with a change percentage of $92 \%$. Panel (C) exhibits the descriptive statistics for the third RD score (RDVariation), where the total mean is 85 with a minimum value of 8 and a maximum value of 85 . The mean value found to increase gradually from 59 to 102 risk-related sentences between the years 2005 and 2015, with a change percentage of 73\%. Finally, Panel (D) shows the descriptive statistics for -Comprehensive. The mean is 356, with a minimum value of 52 and a maximum value of 977 . This indicates that there are some annual reports that contain 977 riskrelated sentences. The mean values appear to increase gradually from 227 in the year 2005 up to 456 in the year 2015, with an increasing percentage of about $100 \%$. Figure (2) shows upward trends for the RD level for the four different RD measures. 
Figure (2): The Mean of RD Level across Years

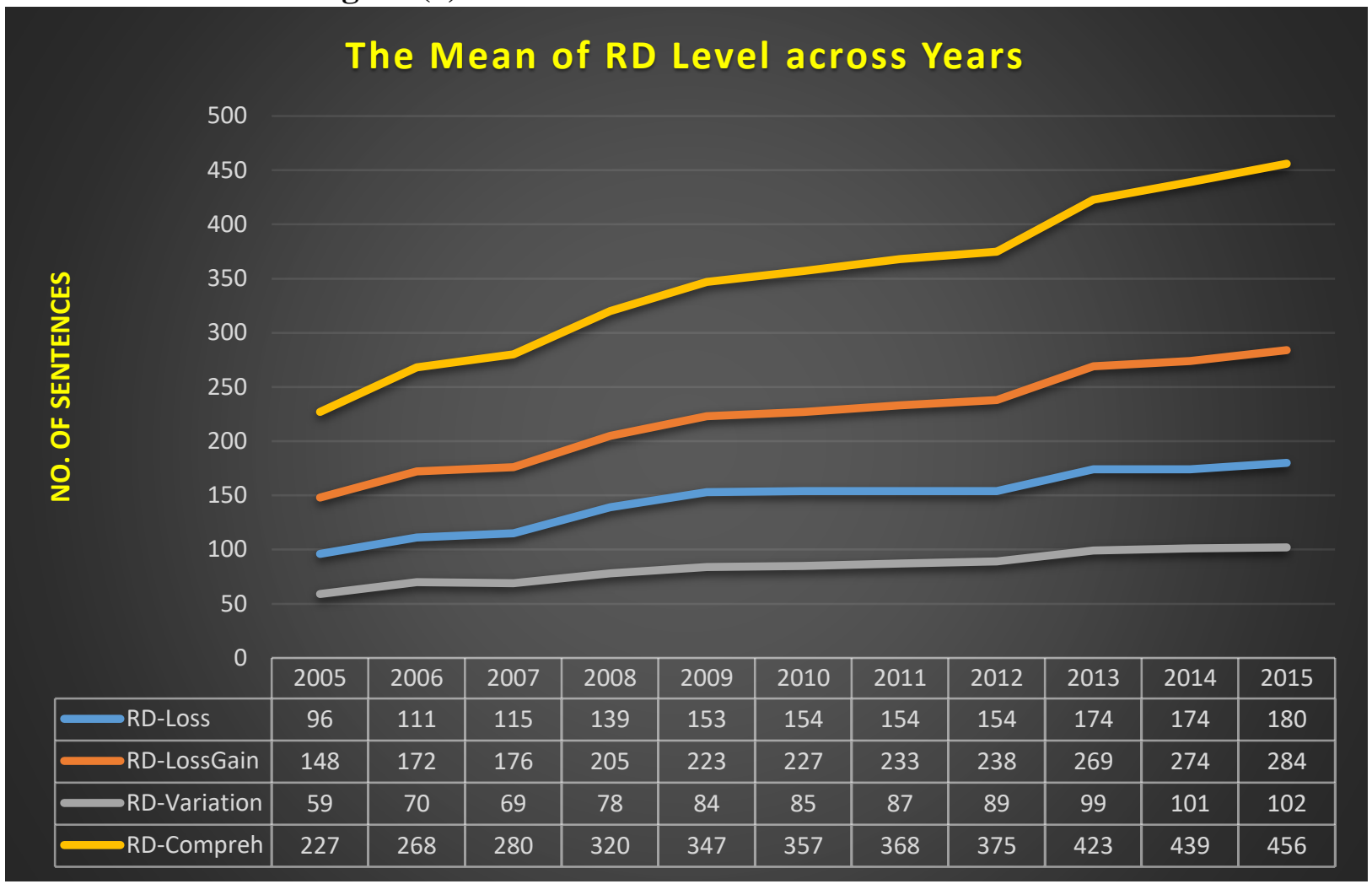

\subsection{Descriptive Statistics of RD across industries}

Table 7 shows the descriptive statistics for the four RD measures across industries. Panel (A) exhibits descriptive statistics for RD-Loss. It is evident that the utility industry presents the highest RD level with a mean of 212, followed by 193 for basic materials, while the technology industry presents the lowest RD level with a mean of 109 risk-related sentences. This implies that the annual reports published by the utilities companies contain 212 risk-related sentences on average, while those published by the technology companies contain 109 risk-related sentences on average. This range is not so much; however, it indicates a degree of variation between the managers' decisions of companies in different industries to disclose risk information. Panel (B) exhibits the descriptive statistics for RD-LossGain. The technology industry continues to show the lowest RD level with a mean value of 174 risk-related sentences, while the utilities industry continues to be the highest with a mean value of 311 sentences. Panel (C) exhibits the descriptive statistics for RD-Variation. However, the Basic materials industry comes at first this time and presents the highest RD with a mean of 120 , followed by the utilities industry with a mean of 119 , while the technology industry continues to be lowest with a mean value of 67 risk-related sentences. Finally, Panel (D) exhibits the descriptive statistics for RD-Comprehensive. The utilities industry again comes at the first with a mean 
value of 486 , followed by basic materials industry with a mean value of 445 , while the technology industry comes at the end as usual.

To conclude, these differences in RD scores between the different industries are expected, since companies in different industries are subject to different operating conditions, different regulations and different risks. In the forward-looking disclosure context, Hassanein (2015) found the same result, where the utilities companies found to show the highest mean and the technology companies found to show the lowest mean and explained that this may be back to the high litigation in the technology industry, which makes companies provide less information disclosure. Finally, Figure (3) presents a clear view of the differences in RD levels between the different industries.

Figure (3): The Mean of RD Level across Industry

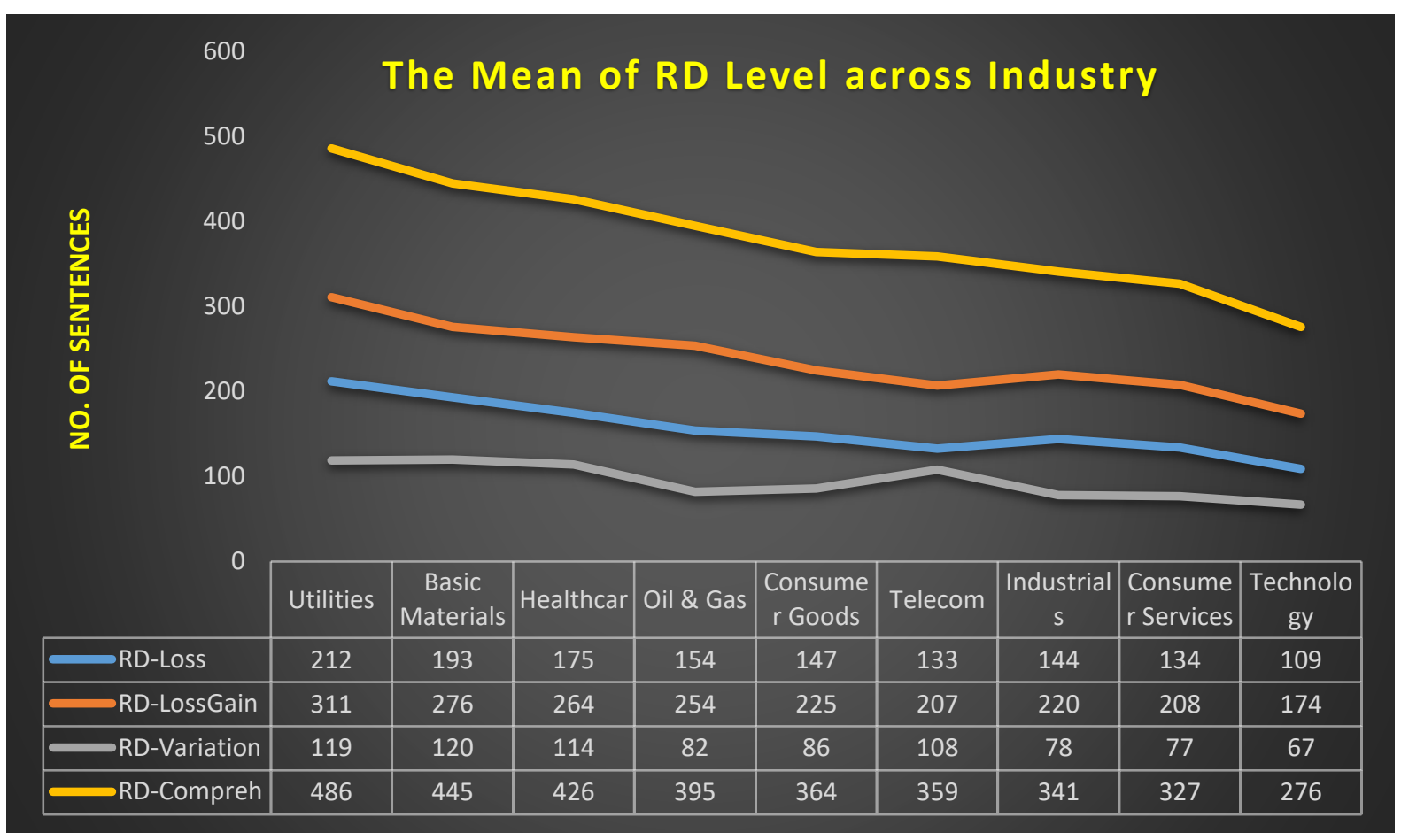

\section{The validity Tests of RD Score}

We conducted several tests, correlations and OLS regressions to ensure the validity of the $\mathrm{RD}$ scores. To ensure that the new suggested keywords are selected properly, the initially selected keywords are selected with the co-author, who is an expert in the content analysis. Then both of us worked to select the most suitable keywords individually, then agreed on final lists. Afterward, the final keywords were sent to an English native speaker who was asked to read these keywords, filter them, and help to determine those that express the different kinds 
of risk. Moreover, we applied a filtering process of two steps: (1) following Hussainey et al. (2003), Hussainey (2004), and Elshandidy (2011), we excluded the risk-related keywords that found to be rarely used in the annual reports by investigating a sample of 150 annual reports, and (2) we also excluded some risk-related keywords that used in a context other than the RD context.

To ensure that the QSR was used in the correct way, the co-author, who proposed and used QSR in counting the disclosure level for the first time (Hussainey et al. 2003), reviewed all the steps that are followed and helped me to generate the command file that was applied later. Then, the 100 risk-related sentences published in Table 1 are read manually to determine whether the selected risk keywords succeed to capture the risk information, these sentences were also reviewed by the co-author. Overall, using the computerized content analysis compared with the manual content analysis is more likely to reduce the probability of any disclosure measurement errors.

\subsection{Correlation Tests}

We also validate our RD scores by linking them with both the cost of capital and firm value. The literature hypothesizes a negative correlation between the disclosure level and cost of capital and a positive correlation between disclosure level and market firm value (e.g., Botosan, 1997; Sengupta, 1998; Richardson \& Welker, 2001; Francis et al. 2005, 2008; Orens et al. 2009; 2010; Kothari et al. 2009; Gordon et al. 2010; Dhaliwal et al. 2011; Ntim et al. 2013; Elzahar et al. 2015; Franco et al. 2016). Accordingly, a sample of 328 non-financial firms constituting FTSE All-Share Index during 2005-2016 has been examined. It is noteworthy that the study RD score is measured for the period 2005-2015, while the data on Cost of Debt and Tobin's Q are collected for the period 2006-2016, where there is one year lag to give an opportunity to the risk-information to affect the markets. Cost of Debt (COD) is used as a proxy of cost of capital and Tobin's Q (Tobin) is used as a proxy of market firm value. A set of control variables have been selected from the literature and added to the models to control for both $\mathrm{COD}$ and Tobin. Bloomberg is the main source for all variables data.

Table (8) shows the Pearson (Parametric) and Spearman (Non-parametric) correlations between $C O D$ and Tobin and each of the four RD-Scores (RD-Loss, RD-LossGain, RDVariation, and $R D$-Compreh). For $C O D$, Table (8) shows a negative and statistically significant correlation between COD and all measures of RD at 1\%, except for RD-Variation. This initial result may refer to a negative influence of RD level on COD, where the higher the RD level in the current year the lower the COD of the next year. In other words, firms with higher RD 
levels may gain debts at lower rates. However, the Tobin results are insignificant except for RD-Loss, where a negative and significant correlation is found.

\begin{tabular}{|l|c|c|c|c|c|}
\hline \multicolumn{5}{|c|}{ Table (8): Pearson and Spearman Correlation Results } \\
\hline Test & & RD-Loss & RD-LossGain & RD-Variation & RD-Compreh \\
\hline $\begin{array}{l}\text { Pearson Correlation } \\
\text { Sig. (2-tailed) }\end{array}$ & COD & $\mathbf{- 0 . 0 8 1 * * *}$ & $\mathbf{- 0 . 0 8 6 * * *}$ & -0.021 & $\mathbf{- 0 . 0 9 8 * * *}$ \\
\cline { 2 - 6 } & Tobin & $\mathbf{- 0 . 0 7 0} * * *$ & -0.039 & -0.063 & -0.023 \\
\hline $\begin{array}{l}\text { Spearman Correlation } \\
\text { Sig. (2-tailed) }\end{array}$ & COD & $\mathbf{- 0 . 1 0 6} * * *$ & $\mathbf{- 0 . 1 2 6 * * *}$ & $\mathbf{- 0 . 0 7 5 * * *}$ & $\mathbf{- 0 . 1 4 5 * * *}$ \\
\cline { 2 - 6 } & Tobin & $\mathbf{- 0 . 0 5 6 * *}$ & -0.012 & 0.016 & 0.002 \\
\hline
\end{tabular}

\subsection{Regression Tests}

Ordinary Least Squares (OLS) regression has been conducted. The regression models include the RD score as the main independent variable and 13 control variables. Ten dummy variables are added to control for the industry effect, and another 3 are included as year dummies. All the variables are winsorised at 1\%. Table (9) shows the results. The results show a negative significant correlation between all RD scores and COD except for the RD-Variation, which is consistent with the literature (e.g., Sengupta, 1998; Dhaliwal et al. 2011; Kothari et al. 2009; Franco et al. 2016). The OLS results of Tobin show a positive and significant relationship between all the RD scores and the market firm value at $1 \%$. The results show also a statistically significant relationship between most of the control variables and the RD scores. These results confirm the validity of RD measurement methods introduced and applied in this study.

\begin{tabular}{|c|c|c|c|c|c|c|c|c|}
\hline \multicolumn{9}{|c|}{ Table (9): The OLS Regression Results } \\
\hline \multirow[b]{3}{*}{$\begin{array}{l}\text { Regression } \\
\text { /Variables }\end{array}$} & \multicolumn{4}{|c|}{ Cost of Debt (COD) } & \multicolumn{4}{|c|}{ Firm Value (Tobin's Q) } \\
\hline & RD-Loss & $\begin{array}{c}\text { RD- } \\
\text { LossGain }\end{array}$ & $\begin{array}{c}\text { RD- } \\
\text { Variation }\end{array}$ & $\begin{array}{c}\text { RD- } \\
\text { Compreh }\end{array}$ & RD-Loss & $\begin{array}{c}\text { RD- } \\
\text { LossGain }\end{array}$ & $\begin{array}{c}\text { RD- } \\
\text { Variation }\end{array}$ & RD-Compreh \\
\hline & $\begin{array}{l}\text { Coefficient } \\
\text { (t-statistic) }\end{array}$ & $\begin{array}{c}\text { Coefficient } \\
\text { (t-statistic) }\end{array}$ & $\begin{array}{c}\text { Coefficient } \\
\text { (t-statistic) }\end{array}$ & $\begin{array}{l}\text { Coefficient } \\
\text { (t-statistic) }\end{array}$ & $\begin{array}{l}\text { Coefficient } \\
\text { (t-statistic) }\end{array}$ & $\begin{array}{l}\text { Coefficient } \\
\text { (t-statistic) }\end{array}$ & $\begin{array}{l}\text { Coefficient } \\
\text { (t-statistic) }\end{array}$ & $\begin{array}{l}\text { Coefficient } \\
\text { (t-statistic) }\end{array}$ \\
\hline RD & $\begin{array}{c}-0.049 * * \\
(-2.23)\end{array}$ & $\begin{array}{c}-0.042 * \\
(-1.72)\end{array}$ & $\begin{array}{l}-0.011 \\
(-0.56)\end{array}$ & $\begin{array}{c}-0.054 * * \\
(-2.15)\end{array}$ & $\begin{array}{c}0.054 * * \\
(2.40)\end{array}$ & $\begin{array}{c}0.094 * * * \\
(3.77)\end{array}$ & $\begin{array}{c}0.076 * * * \\
(3.72)\end{array}$ & $\begin{array}{c}0.104 * * * \\
(4.08)\end{array}$ \\
\hline No. & 1,764 & 1,764 & 1,764 & 1,764 & 1,762 & 1,762 & 1,762 & 1,762 \\
\hline Adj. R2 & 0.36 & 0.36 & 0.36 & 0.36 & 0.30 & 0.31 & 0.30 & 0.3045 \\
\hline F-value & $\begin{array}{c}43.09 \\
(0.000) \\
\end{array}$ & $\begin{array}{c}42.96 \\
(0.000) \\
\end{array}$ & $\begin{array}{c}42.78 \\
(0.000) \\
\end{array}$ & $\begin{array}{c}43.07 \\
(0.000) \\
\end{array}$ & $\begin{array}{c}32.47 \\
(0.000) \\
\end{array}$ & $\begin{array}{c}32.98 \\
(0.000) \\
\end{array}$ & $\begin{array}{c}32.96 \\
(0.000) \\
\end{array}$ & $\begin{array}{c}33.13 \\
(0.000) \\
\end{array}$ \\
\hline Controls & \multicolumn{8}{|c|}{ Included } \\
\hline $\begin{array}{l}\text { Industry } \\
\text { Dummies }\end{array}$ & \multicolumn{8}{|c|}{ Included } \\
\hline
\end{tabular}


The study results present the following implications. First, the study presents evidence that risk should be defined from the negative side only and provides a new definition of RD accordingly. The new RD definition is not a substitute rather it is complementary, where the study extends the literature by adding one more definition of RD. Currently, researchers have three definitions, the one presented by this study that researchers can use if they adopt the premodern view of risk as losses only, the second presented by Linsley \& Shrives (2006) if they adopt the modern view of risk concept, and the third presented by Elshandidy (2011) if they adopt the variation definition of risk. The study contributes by adding more options to RD researchers. It is noteworthy that the new definition of RD presented by this study is not a substitute to the existing definitions but a new definition from a different perspective, despite the fact that we strongly recommend defining risk as losses only and using that definition.

Regardless of the RD measurement method used, researchers should define precisely what they mean by risk and risk information and which view they would adopt, before measuring the RD score. Risk researchers have to consider the three different concepts of "Risk" before engaging in any risk-related research. Then, they should justify the definition of RD that they would adopt. Several studies found to adopt the definition of RD presented by Linsley \& Shrives (2006) without any justification, why did they follow the modern view not the premodern or the variation view was not justified or discussed. Moreover, RD researchers should be clear and precise on the keywords used to measure RD score, the keywords should be highly consistent with the adopted risk view. The study presents new keywords that are used for the first time in the measurement of RD score and represent the three different views, which could help researchers develop their own lists of risk-related keywords.

From the perspectives of regulators, accounting standards setters and companies, it is more worthy to define the risk before setting any risk-related standards, regulations, or guidelines. From our review of the regulations and the guidelines that aim to organize RD, we noticed that risk is not defined clearly, which may leave the readers confused. Moreover, it could be more worthy that the preparers of annual reports announce about their definition of risk before disclosing any risk information. 


\section{Conclusion}

This study aims to develop the measurement of narrative risk disclosure. The study contributes by extending the ongoing debate on whether the positive outcomes of events should be considered in the risk definition or not. The study proposes a new definition of RD based on the pre-modern view of risk. This definition is formulated after conducting two empirical tests on a sample of annual reports of UK firms. The results confirm the study arguments that the risk information should be prepared and explained as losses only. The first empirical test shows that about $94 \%$ of risk information in annual reports is talking about negative outcomes. The second test shows that $87 \%$ of the risk-related sentences in the annual reports discussing risks using negative keywords.

Afterward, the study contributes by developing lists of risk-related keywords that are consistent with the study proposed RD definition and the other definitions in the literature. The first list consists of 60 keywords that express and measure the risk as negative outcomes only, a second list consists of 75 keywords to express and measure the risk as both negative and positive outcomes, while the third list consists of 7 keywords to express and measure the risk as a variation around a target. Moreover, a comprehensive list of all these keywords in addition to the "risk" and "uncertainty" keywords is created to measure the RD score as a comprehensive score. Then, these proposed keywords are applied to measure RD scores for a sample of 328 non-financial firms listed on FTSE All-Share Index during 2005-2015. Several validity tests were applied to ensure the validity of RD scores, correlation and regression tests were run and provide expected results consistent with the literature.

The descriptive statistics of RD scores show that the overall trend increases over the period (2005-2015) for the four measures. The score of RD-Compreh score is the highest across the study period, while the score for RD-Variation is the lowest. The utilities industry found to report the highest RD score, while the technology industry found to report the lowest RD score across the nine examined industries.

The study ends with important implications for risk-interested researchers and other business community members. The study main argument is that risk should be defined from the negative side only. Although people understand risks as losses, the RD literature defines RD differently; once as losses only (e.g., Lupton, 1999; Horcher, 2005), once as losses and gains (e.g., Linsley \& Shrives, 2006), and once and a variation (e.g., Abraham \& Cox, 2007; Elshandidy, 2011). However, the study presents five theoretical arguments for why RD should be defined as negative outcomes only. The results of the empirical tests confirm these 
arguments. Regardless of the RD measurement method used, researchers should define precisely what they mean by risk and risk information before measuring the RD score. Moreover, accounting standard setters and other regulators should announce clearly what they mean by risk.

Future research should contribute to the ongoing debate and provide more evidence on whether positive outcomes should be included in the risk definition or not. More investigation is still required on the value-relevance of RD defined from the three different perspectives, which one is more value-relevant is an interesting question.

\section{References}

Abraham, S., Cox, P., 2007. Analysing the determinants of narrative risk information in UK FTSE 100 annual reports. The British Accounting Review 39, 227-248.

Adams, J. 2009. Risk. $6^{\text {th }}$ edition, UCL, London, UK

Al-Shammari, B., 2014. An investigation of the impact of corporate governance mechanisms on level of corporate risk disclosure: evidence from Kuwait. International Journal of Business and Social Research 4, 51-70.

Atanasovski, A., Serafimoska, M., Jovanovski, K., Jovevski, D., 2015. Risk disclosure practices in annual reports of listed companies: evidence from a developing country. Research Journal of Finance and Accounting 6 , 184-192.

Beattie, V., McInnes, B., Fearnley, S., 2004. A methodology for analysing and evaluating narratives in annual reports: a comprehensive descriptive profile and metrics for disclosure quality attributes. Accounting Forum 28, 205-236.

Berger, P.G., 2011. Challenges and opportunities in disclosure research - a discussion of 'the financial reporting environment: Review of the recent literature'. Journal of Accounting and Economics 51, 204-218.

Beyer, A., Cohen, D.A., Lys, T.Z., Walther, B.R., 2010. The financial reporting environment: Review of the recent literature. Journal of Accounting and Economics 50, 296-343.

Botosan, C.A., 1997. Disclosure Level and the Cost of Equity Capital. The Accounting Review 72, 323-349.

Copeland, R.M., Fredericks, W., 1968. Extent of Disclosure. Journal of Accounting Research 6, 106-113.

Core, J.E., 2001. A review of the empirical disclosure literature: discussion. Journal of Accounting and Economics 31, 441-456.

Deumes, R., 2008. Corporate Risk Reporting: A Content Analysis of Narrative Risk Disclosures in Prospectuses. Journal of Business Communication 45, 120-157.

Dobler, M., Lajili, K, \& Zeghal, D. 2011. Attributes of corporate risk disclosure: an international investigation in the manufacturing sector. Journal of International Accounting Research 10 (2): 1-22.

El-Gazzar, S. M., Chung, K.-H. \& Jacob, R. A. 2011. Reporting of Internal Control Weaknesses and Debt Rating Changes. International Advances in Economic Research, 17, 421-435.

Elshandidy, T. \& Neri, L. 2015. Corporate Governance, Risk Disclosure Practices, and Market Liquidity: Comparative Evidence from the UK and Italy. Corporate Governance: An International Review, 23, 331356.

Elshandidy, T. M. F. 2011. Risk Reporting Incentives: A cross-country Study. PhD Thesis. Stirling Management School. Stirling University. UK.

Elshandidy, T., Fraser, I. \& Hussainey, K. 2013. Aggregated, voluntary, and mandatory risk disclosure incentives: Evidence from UK FTSE all-share companies. International Review of Financial Analysis, 30, 320-333.

Elshandidy, T., Fraser, I. \& Hussainey, K. 2015. What drives mandatory and voluntary risk reporting variations across Germany, UK and US? The British Accounting Review, 47, 376-394.

Elzahar, H., Hussainey, K., 2012. Determinants of narrative risk disclosures in UK interim reports. The Journal of Risk Finance 13, 133-147.

Elzahar, H., Hussainey, K., Mazzi, F., Tsalavoutas, I., 2015. Economic consequences of key performance indicators' disclosure quality. International Review of Financial Analysis 39, 96-112. 
Filzen, J.J., 2015. The Information Content of Risk Factor Disclosures in Quarterly Reports. Accounting Horizons 29, 887-916.

Francis, J., Nanda, D. \& Olsson, P. E. R. 2008. Voluntary Disclosure, Earnings Quality, and Cost of Capital. Journal of Accounting Research, 46, 53-99.

Franco, F., Urcan, O. \& Vasvari, F. P. 2016. Corporate Diversification and the Cost of Debt: The Role of Segment Disclosures. The Accounting Review, 91, 1139-1165.

FRC. 2014. Guidance on Risk Management, Internal Control and Related Financial and Business Reporting. Financial Reporting Council (FRC): London.

Frolov, M., 2006. Bank credit risk disclosure in Japan. Journal of Banking Regulation 7, 221-242.

GAS 5. 2001. German Accounting Standard No. 5. Risk Reporting. GASB: Germany.

Gelb, D. S., Zarowin. P., 2002. Corporate disclosure policy and the informativeness of stock prices. Review of Accounting Studies 7, 33-52.

Gordon, L. A., Loeb, M. P., and Sohail, T. 2010. Market value of voluntary disclosures concerning information security. MIS Quarterly 34 (3), 567-594.

Gray, R., Haslam, J., 1990. External reporting by UK University: an exploratory study of accounting change. Financial Accounting and Management 6, 51-72.

Greco, G., 2012. The management's reaction to new mandatory risk disclosure. Corporate Communications: An International Journal 17, 113-137.

Gruning, M., 2011. Artificial intelligence measurement of disclosure (AIMD). European Accounting Review 20, 485-519.

Habbash, M., Hussainey, K., Awad, A. E., 2016. The determinants of voluntary disclosure in Saudi Arabia: an empirical study. International Journal of Accounting, Auditing and Performance evaluation (IJAAPE) 12, 213-236.

Hassan, K. M. 2009. UAE corporations-specific characteristics and level of risk disclosure. Managerial Auditing Journal, 24, 668-687.

Hassan, O. and Marston, C. 2010. Disclosure Measurement in the Empirical Accounting Literature: A Review Article. Working Paper No. 10-18, Economics and Finance Working Paper Series, Brunel University, London. http://dx.doi.org/10.2139/ssrn.1640598

Hassanein, A. A. A. 2015. Informativeness of unaudited forward-looking financial disclosure: evidence from UK narrative reporting. PhD Thesis, Plymouth Business School, Plymouth University, UK

Healy, P.M., Hutton, A.P., Palepu, K.G., 1999. Stock Performance and Intermediation Changes Surrounding Sustained Increases in Disclosure. Contemporary Accounting Research 16, 485-520.

Healy, P.M., Palepu, K.G., 2001. Information asymmetry, corporate disclosure, and the capital markets: A review of the empirical disclosure literature. Journal of Accounting and Economics 31, 405-440.

Helbok, G., Wagner, C., 2006. Determinants of operational risk reporting in the banking industry. Journal of Risk 9, 49-74.

Henry, E. 2008. Are Investors Influenced By How Earnings Press Releases Are Written? Journal of Business Communication, 45, 363-407.

Hill, P., Short, H., 2009. Risk disclosures on the second tier markets of the London Stock Exchange. Accounting \& Finance 49, 753-780.

Hodder, L., Koonce, L., McAnally, M.L., 2001. SEC market risk implications for judgement and decision making. Accounting Horizons 15 (1), 49-70.

Horcher, K. 2005. Managing treasury risks in the real world. Journal of Corporate Accounting \& Finance, 17, 23-32.

Hussainey, K. S. M. 2004. A study of the ability of (partially) automated disclosure scores to explain the information content of annual report narratives for future earnings. PhD Thesis. Manchester School of Accounting and Finance. Manchester University, UK.

Iatridis, G., 2008. Accounting disclosure and firms' financial attributes: Evidence from the UK stock market. International Review of Financial Analysis 17, 219-241.

ICAEW. 1997. Financial reporting of risk: proposal for a statement of business risk. Institute of Chartered Accountants in England and Wales (ICAEW): London.

ICAEW. 1999. No surprises: the case for better risk reporting. Institute of Chartered Accountants in England and Wales (ICAEW): London.

ICAEW. 2002. No surprises: working for better risk disclosure. Institute of Chartered Accountants of England and Wales (ICAEW): London. 
ICAEW. 2011. Reporting business risks: meeting expectations. Institute of Chartered Accountants of England and Wales (ICAEW): London.

ICAEW. 2017. What is next for corporate reporting: time to decide? Institute of Chartered Accountants of England and Wales (ICAEW): London.

IFRS 7. 2008. International Financial Reporting Standard No.7: financial instruments: disclosures. IASB: London.

IIRC. 2013. The International Integrated Reporting Framework. International Integrated Reporting Council (IIRC): London.

Kaplan, S. \& Garrick, B. J. 1981. On The Quantitative Definition of Risk. Risk Analysis, 1, 11-27.

Kothari, S.P., Li, X., Short, J.E., 2009. The Effect of Disclosures by Management, Analysts, and Business Press on Cost of Capital, Return Volatility, and Analyst Forecasts: A Study Using Content Analysis. The Accounting Review 84, 1639-1670.

Kravet, T., Muslu, V., 2013. Textual risk disclosures and investors' risk perceptions. Review of Accounting Studies $18,1088-1122$.

Krippendorff. K. 2013. Content Analysis: An Introduction to its Methodology. Third Edition. Sage Publications, Inc. USA.

Linsley, P. M., Shrives, P. J. \& Crumpton, M. 2006. Risk disclosure: An exploratory study of UK and Canadian banks. Journal of Banking Regulation, 7, 268-282.

Linsley, P.M., Lawrence, M.J., 2007. Risk reporting by the largest UK companies: readability and lack of obfuscation. Accounting, Auditing \& Accountability Journal 20, 620-627.

Linsley, P.M., Shrives, P.J., 2005. Examining risk reporting in UK public companies. The Journal of Risk Finance 6, 292-305.

Linsley, P.M., Shrives, P.J., 2006. Risk reporting: A study of risk disclosures in the annual reports of UK companies. The British Accounting Review 38, 387-404.

Lipunga, A. M. 2014. Risk disclosure practices of Malawian commercial banks. Journal of Contemporary Issues in Business Research 3 (3), 154-167.

Lupton, D. 1999.Risk (Key Ideas). Routledge, London.

Marzouk, M. K., 2016. Risk reporting during a crisis: evidence from the Egyptian capital market. Journal of Applied Accounting Research 17 (4), 378-396.

Meek, G.K., Roberts, C.B., Gray, S.J., 1995. Factors Influencing Voluntary Annual Report Disclosures by U.S., U.K. and Continental European Multinational Corporations. Journal of International Business Studies 26, 555-572.

Miihkinen, A., 2012. What Drives Quality of Firm Risk Disclosure? The International Journal of Accounting 47, 437-468.

Milne, M.J., Adler, R.W., 1999. Exploring the reliability of social and environmental disclosures content analysis. Accounting, Auditing \& Accountability Journal 12, 237-256.

Mokhtar, E. \& Mellett, H. 2013. Competition, corporate governance, ownership structure and risk reporting. Managerial Auditing Journal, 28, 838-865.

Moumen, N., Ben Othman, H., Hussainey, K., 2015. The value relevance of risk disclosure in annual reports: Evidence from MENA emerging markets. Research in International Business and Finance 34, 177-204.

Ntim, C.G., Lindop, S., Thomas, D.A., 2013. Corporate governance and risk reporting in South Africa: A study of corporate risk disclosures in the pre- and post-2007/2008 global financial crisis periods. International Review of Financial Analysis 30, 363-383.

Orens, R., Aerts, W. \& Cormier, D. 2010. Web-Based Non-Financial Disclosure and Cost of Finance. Journal of Business Finance \& Accounting, 37, 1057-1093.

Orens, R., Aerts, A., and Lybaert, N. 2009. Intellectual Capital Disclosure: cost of finance and firm value. Management Decision 47 (10), 1536-1554.

Rajab, B. 2009. Corporate Risk Disclosure: its determinants and its impact on the company's cost of equity capital. PhD Thesis. Business School, Edinburgh Napier University, UK

Rajab, B., Schachler, M. H., 2009. Corporate risk disclosure by UK firms: trends and determinants. World Review of Entrepreneurship, Management and Sustainable Development 5, 224.

Richardson, A. J. \& Welker, M. 2001. Social disclosure, financial disclosure and the cost of equity capital. Accounting, Organizations and Society, 26, 597-616.

Riley, J., Taylor, E. Z., 2015., The effect of risk disclosure readability on nonprofessional investors. Available at: http://ssrn.com/abstract $=2519227$

Schrand, C. \& Elliott, J. 1998. Risk and financial reporting: A summary of the discussion at the 1997 AAA/FASB conference. Accounting Horizon, 12(3), 271-282. 
Sengupta, P., 1998. Corporate disclosure quality and the cost of debt. The Accounting Review 73, 459-474.

Solomon, J. F., Solomon, A., Norton, S. D., \& Joseph, N. L. 2000. A Conceptual Framework for Corporate Risk

Disclosure Emerging from the Agenda for Corporate Governance Reform. The British Accounting Review 32 (4), $447-478$.

Sun, Y., 2015. Internal Control Weakness Disclosure and Firm Investment. Journal of Accounting, Auditing \& Finance 31, 277-307.

Tauringana, V., Chithambo, L., 2016. Determinants of risk disclosure compliance in Malawi: a mixed-method approach. Journal of Accounting in Emerging Economies 6, 111-137.

Welker, M., 1995. Disclosure Policy, Information Asymmetry, and Liquidity in Equity Markets. Contemporary Accounting Research 11, 801-827.

Woods, M., Marginson, D.E.W., 2004. Accounting for derivatives: An evaluation of reporting practice by UK banks. European Accounting Review 13, 373-390. 


\begin{tabular}{|c|c|c|}
\hline \multicolumn{3}{|c|}{ Table (1): A Test of RISK in a sample of 150 annual reports } \\
\hline No & Sentence & $\begin{array}{c}\text { Negative } \\
\text { or Positive } \\
\text { Outcomes }\end{array}$ \\
\hline \multicolumn{3}{|c|}{ Panel (A): Risk Sentences Discussing Risk as a Loss } \\
\hline 1 & $\begin{array}{l}\text { Some of the countries in which the Group operates have a reputation for corruption, and given } \\
\text { that many of our contracts involve large sums of money, we are at RISK of being accused of } \\
\text { bribery and other unethical behaviour. }\end{array}$ & Negative \\
\hline 2 & $\begin{array}{l}\text { There will be persistent RISKs of shocks coming from a combination of events and } \\
\text { regulatory action in the financial markets and the painful fiscal adjustments into which } \\
\text { Governments have been forced. }\end{array}$ & Negative \\
\hline 3 & $\begin{array}{l}\text { The RISKs include, but are not limited to, Terrorism, hostage taking, military repression, } \\
\text { expropriation, extreme fluctuations in currency exchange rates, high rates of inflation and } \\
\text { labour unrest. }\end{array}$ & Negative \\
\hline 4 & $\begin{array}{l}\text { As well as credit RISK exposures inherent within the Group's outstanding receivables the } \\
\text { group is exposed to counterparty credit RISK arising from the placing of deposits and } \\
\text { entering into derivative financial instrument contracts with banks and financial institutions. }\end{array}$ & Negative \\
\hline 5 & $\begin{array}{l}\text { The Board has considered the probability of those RISKs occurring and their impact, as well } \\
\text { as the actions that would be taken in response to them if they did occur. }\end{array}$ & Negative \\
\hline 6 & $\begin{array}{l}\text { Our greatest exposure lies in our International Power Projects business, and they perform } \\
\text { RISK assessments on a contract-by-contract basis. }\end{array}$ & Negative \\
\hline 7 & $\begin{array}{l}\text { Our business continues to have a low environmental impact and its activities are not expected } \\
\text { to give rise to any significant environmental RISK over the next twelve months. }\end{array}$ & Negative \\
\hline 8 & $\begin{array}{l}\text { Commercial property development remains difficult; the combination of construction, tenant } \\
\text { and valuation RISK means that it is still very hard to generate development profits. }\end{array}$ & Negative \\
\hline 9 & $\begin{array}{l}\text { The bad weather experienced at the end of } 2009 \text { and early } 2010 \text { will undoubtedly reduce } \\
\text { traffic volumes and income but we have a fixed price gritting contract on the route, which } \\
\text { takes on the bad weather RISK, and therefore we will not face any additional costs. }\end{array}$ & Negative \\
\hline 10 & $\begin{array}{l}\text { This RISK assessment highlights to the Group what makes the product safe and flags if there } \\
\text { are any potential hazards with the product. }\end{array}$ & Negative \\
\hline 11 & $\begin{array}{l}\text { In addition, specialist third party consultants are tasked from time to time to perform an } \\
\text { internal audit of a specific key business RISK, for example the Company's compliance with } \\
\text { environmental and health \& safety requirements. }\end{array}$ & Negative \\
\hline 12 & $\begin{array}{l}\text { The principal financial RISKs to which the Group is exposed through its activities are RISKs } \\
\text { of changes in foreign currency exchange rates and interest rates. }\end{array}$ & Negative \\
\hline 13 & $\begin{array}{l}\text { We recognise the RISKs associated with operating an airline and work tirelessly to ensure } \\
\text { the safety of our customers, our people and our shareholders' investments. }\end{array}$ & Negative \\
\hline 14 & $\begin{array}{l}\text { The Group's exposures to interest rates on financial assets and financial liabilities are detailed } \\
\text { in the liquidity RISK management section of this note. }\end{array}$ & Negative \\
\hline 15 & $\begin{array}{l}\text { Such contracts enable the Group to mitigate the RISK of changing interest rates on the cash } \\
\text { flow exposures on the issued variable rate debt held. }\end{array}$ & Negative \\
\hline 16 & $\begin{array}{l}\text { The Group's operations expose it to a variety of RISKs and uncertainties, including: Market } \\
\text { RISK: The Group provides a range of products and services, and there is a RISK that the } \\
\text { demand for these services will vary from time to time because of competitor action or } \\
\text { economic cycles. }\end{array}$ & Negative \\
\hline 17 & $\begin{array}{l}\text { Such development projects carry business RISKs, including reputational RISK, abortive } \\
\text { expenditure and potential customer claims which may have a material impact on the Group. }\end{array}$ & Negative \\
\hline 18 & $\begin{array}{l}\text { The credit RISK on liquid funds is limited because the counterparties are banks with high } \\
\text { credit ratings assigned by international credit rating agencies. }\end{array}$ & Negative \\
\hline 19 & $\begin{array}{l}\text { These systems are designed to manage, rather than eliminate, the RISK of failure to achieve } \\
\text { business objectives and consequently can provide reasonable, but not absolute, assurance } \\
\text { against material mis-statement or loss. }\end{array}$ & Negative \\
\hline 20 & $\begin{array}{l}\text { The Group's overall RISK management programme focuses on the unpredictability of } \\
\text { commodity and financial markets and seeks to manage potential adverse effects on the } \\
\text { Group's financial performance. }\end{array}$ & Negative \\
\hline
\end{tabular}




\begin{tabular}{|c|c|c|}
\hline 21 & $\begin{array}{l}\text { Workplace hazards are formally RISK assessed and appropriate control measures (physical } \\
\text { and procedural) are implemented. }\end{array}$ & Negative \\
\hline 22 & $\begin{array}{l}\text { As the Group has large cash resources to meet these payments and financing is arranged for } \\
\text { the aircraft prior to delivery, no significant funding RISK is perceived. }\end{array}$ & Negative \\
\hline 23 & There is a RISK that the number of deaths in any year significantly reduces. & Negative \\
\hline 24 & $\begin{array}{l}\text { The RISK is also mitigated by recruiting and developing a strong finance function, which is } \\
\text { focused on ensuring the accuracy and integrity of the reported results. }\end{array}$ & Negative \\
\hline 25 & $\begin{array}{l}\text { These RISKs include the RISK of inadequate or failed internal and external processes and } \\
\text { systems, departure of key management personnel, human error and external events such as } \\
\text { changes in credit terms offered by suppliers, major disruption to delivery services or to the } \\
\text { product supply chain. }\end{array}$ & Negative \\
\hline 26 & Borrowings issued at variable rates expose the Group to cash flow interest rate RISK. & Negative \\
\hline 27 & $\begin{array}{l}\text { Its principal duties are to monitor the integrity of the financial statements, to review the } \\
\text { internal controls and RISK management systems, to review the work of internal audit and to } \\
\text { consider all aspects of the relationship with the external auditors. }\end{array}$ & Negative \\
\hline 28 & $\begin{array}{l}\text { The Group mitigates interest rate RISK on its borrowings by matching, to the extent possible, } \\
\text { the maturity of its cash balances with the interest rate reset periods on the swaps related to its } \\
\text { borrowings. }\end{array}$ & Negative \\
\hline 29 & $\begin{array}{l}\text { Over time, therefore, we have developed a comprehensive range of operating procedures and } \\
\text { processes to ensure that we minimise any RISK of harm to people or to the environment. }\end{array}$ & Negative \\
\hline 30 & $\begin{array}{l}\text { The group's increasing dependence on information systems has also heightened the } \\
\text { information security RISK to the group with breaches in our data security systems having a } \\
\text { potential impact on our business and reputation. }\end{array}$ & Negative \\
\hline 31 & $\begin{array}{l}\text { There is also a RISK of tax laws being amended by authorities in the different jurisdictions } \\
\text { in which the group operates which could have an adverse effect on the financial results. }\end{array}$ & Negative \\
\hline 32 & $\begin{array}{l}\text { Concentration of credit RISK with respect to trade receivables is limited due to the group's } \\
\text { customer base being large and diverse. }\end{array}$ & Negative \\
\hline 33 & $\begin{array}{l}\text { Business RISKs: HRG operates in a highly competitive market and HRG may not react } \\
\text { adequately to changes in the corporate travel market; general economic downturns such as } \\
\text { the current macro-economic crisis, terrorism, the fear of terrorism, travel industry strikes, } \\
\text { fuel price escalation, national disasters, health pandemics or similar events could reduce } \\
\text { revenues. }\end{array}$ & Negative \\
\hline 34 & $\begin{array}{l}\text { As a result of the recent and ongoing financial crisis, the Company has evaluated and } \\
\text { introduced additional efforts to try to mitigate credit RISK exposure. }\end{array}$ & Negative \\
\hline 35 & $\begin{array}{l}\text { The Group mitigates liquidity RISK by managing the cash generation of its operations, } \\
\text { combined with bank borrowings and long-term debt. }\end{array}$ & Negative \\
\hline 36 & The group's interest rate RISK arises from long-term borrowings. & Negative \\
\hline 37 & All potentially hazardous activities are formally RISK assessed. & Negative \\
\hline 38 & $\begin{array}{l}\text { The Audit Committee reviewed the Company's internal controls and RISK management } \\
\text { systems by considering the Group's RISK assessment process and the effectiveness of the } \\
\text { controls to mitigate those RISKs. }\end{array}$ & Negative \\
\hline 39 & $\begin{array}{l}\text { The Group takes its responsibilities seriously and contracts may be allocated to dedicated } \\
\text { teams with audits performed to reduce the RISK of non-compliance. }\end{array}$ & Negative \\
\hline 40 & $\begin{array}{l}\text { These policies and guidelines primarily cover foreign exchange RISKy commodity price } \\
\text { RISKy credit RISKy liquidity RISK and interest rate RISK. }\end{array}$ & Negative \\
\hline 41 & Further detail on the principal RISKs facing the Group is set out below. & Negative \\
\hline 42 & $\begin{array}{l}\text { Identification of hazards assessment of the RISKs and the introduction of control measures } \\
\text { form the basis of these systems. }\end{array}$ & Negative \\
\hline 43 & $\begin{array}{l}\text { It considers whether the significant RISKs faced by the Group are being identified, evaluated } \\
\text { and appropriately managed, having regard to the balance of RISK, cost and opportunity. }\end{array}$ & Negative \\
\hline 44 & $\begin{array}{l}\text { The RISK of failure of counterparties to these instruments and of the investment manager is } \\
\text { monitored regularly by the Committee; as such failure could expose the scheme to loss. }\end{array}$ & Negative \\
\hline 45 & Reduced liquidity could put at RISK our ability to meet loan and other trading commitments. & Negative \\
\hline 46 & The RISK of the auditor withdrawing from the market was also considered. & Negative \\
\hline 47 & $\begin{array}{l}\text { We continue to make significant progress in reducing the RISK of injury to employees; as a } \\
\text { result, the number of reportable accidents has reduced again this year. }\end{array}$ & ative \\
\hline 48 & $\begin{array}{l}\text { In order to hedge its exposure to certain foreign exchange RISKs, the Group enters into } \\
\text { forward contracts. }\end{array}$ & Negative \\
\hline
\end{tabular}




\begin{tabular}{|c|c|c|}
\hline 49 & $\begin{array}{l}\text { The Group strives to avoid occupational illnesses by taking all necessary steps to provide a } \\
\text { working environment that minimises any RISK to the health of its workers. }\end{array}$ & Negative \\
\hline 50 & $\begin{array}{l}\text { To date the Group has also had a low level of bad debt in the IPP business although the RISK } \\
\text { of a major default is high. }\end{array}$ & Negative \\
\hline 51 & $\begin{array}{l}\text { There is a RISK that fraud or accounting discrepancies may occur if the financial and } \\
\text { operational control framework is inadequate. }\end{array}$ & Negative \\
\hline 52 & $\begin{array}{l}\text { Trade receivables are the main source of credit RISK to the Group. However, this RISK is } \\
\text { minimised as much as possible through well-established credit control procedures. }\end{array}$ & Negative \\
\hline 53 & $\begin{array}{l}\text { The Company's operations are subject to all of the hazards and RISKs normally incident to } \\
\text { mineral exploration, mine development and operation, any of which could result in damage } \\
\text { to life or property, environmental damage and possible legal liability for any or all damage. }\end{array}$ & Negative \\
\hline 54 & $\begin{array}{l}\text { We mitigate this RISK by retaining the ability to react quickly to changes in customer } \\
\text { demand and to adjust our offer accordingly. }\end{array}$ & Negative \\
\hline 55 & $\begin{array}{l}\text { In some jurisdictions there are significant RISKs of political instability which can result in } \\
\text { civil unrest, equipment seizure, renegotiation or nullication of existing agreements, changes } \\
\text { in laws, taxation policies or currency restrictions. }\end{array}$ & Negative \\
\hline 56 & $\begin{array}{l}\text { As stated in our accounting policies Note } 1 \text { on page } 83 \text { the activities of the Group expose it } \\
\text { directly to the financial RISKs of changes in foreign currency exchange rates and interest } \\
\text { rates. }\end{array}$ & Negative \\
\hline 57 & AMEC is exposed to the RISK that the IT systems upon which it relies fail. & Negative \\
\hline 58 & $\begin{array}{l}\text { These procedures include ongoing monthly functional reviews designed to identify, evaluate } \\
\text { and manage the significant RISKs faced by the company. }\end{array}$ & Negative \\
\hline 59 & $\begin{array}{l}\text { The Group prides itself on maintaining good relationships with suppliers and subscribes to } \\
\text { multiple information sources and organisations that deal with food safety, which allows the } \\
\text { Group to see current and potential emerging RISKs and as a result prepare accordingly. }\end{array}$ & Negative \\
\hline 60 & $\begin{array}{l}\text { Should any of the RISKs actually materialise then Delight's business, financial condition, } \\
\text { prospects and share price could be materially and adversely affected. }\end{array}$ & Negative \\
\hline 61 & $\begin{array}{l}\text { The group seeks to limit interest rate and foreign currency RISKs described above by the use } \\
\text { of financial instruments and as a result has a credit RISK from the potential non-performance } \\
\text { by the counterparties to these financial instruments, which are unsecured. }\end{array}$ & Negative \\
\hline 62 & $\begin{array}{l}\text { Once appointed, the RISK manager will report to the Chief Financial Officer and be } \\
\text { responsible for identifying potential RISKs and proposing procedures and controls to } \\
\text { mitigate such RISKs. }\end{array}$ & Negative \\
\hline 63 & $\begin{array}{l}\text { All food safety and quality systems depend upon identifying the RISKs and potential } \\
\text { hazards. }\end{array}$ & Negative \\
\hline 64 & $\begin{array}{l}\text { In order to reduce the currency RISK arising, the Group uses direct borrowings in the same } \\
\text { currency as those investments. }\end{array}$ & Negative \\
\hline 65 & $\begin{array}{l}\text { The Board recognises the need to identify areas of significant business RISK and to develop } \\
\text { and implement strategies to mitigate these risks. }\end{array}$ & Negative \\
\hline 66 & $\begin{array}{l}\text { The objective of liquidity RISK management is to ensure sufficient cash resources and the } \\
\text { availability of funding as required. }\end{array}$ & Negative \\
\hline 67 & $\begin{array}{l}\text { The economic entity has adopted a policy of only dealing with credit-worthy counter-parties } \\
\text { and obtaining sufficient collateral or other security where appropriate, as a means of } \\
\text { mitigating the RISK of financial loss from defaults. }\end{array}$ & Negative \\
\hline 68 & $\begin{array}{l}\text { Like all businesses, we face the RISK of increased costs from compliance with new laws and } \\
\text { regulations. }\end{array}$ & Negative \\
\hline 69 & $\begin{array}{l}\text { The inability of the Group to supply against contractual commitments is a RISK which could } \\
\text { have an adverse impact on the business. }\end{array}$ & Negative \\
\hline 70 & $\begin{array}{l}\text { As Drax relies on third-party suppliers for the delivery of coal and other goods and services, } \\
\text { it is exposed to the RISK of non-performance by these third-party suppliers. }\end{array}$ & Negative \\
\hline 71 & $\begin{array}{l}\text { On a regular basis, it will receive reports on RISK management, fraud, legal and corporate } \\
\text { governance matters, in order to help it assess the effectiveness of the RISK management and } \\
\text { control frameworks. }\end{array}$ & Negative \\
\hline 72 & $\begin{array}{l}\text { The Group is required to formally review the principal areas of RISK and uncertainty for all } \\
\text { its businesses in order for the major RISKS to be addressed at all levels. }\end{array}$ & Negative \\
\hline 73 & $\begin{array}{l}\text { Because a number of fiscal periods remain open to review by the tax authorities, coupled } \\
\text { with the complexity of the Group and the transactions they have undertaken, there remains a } \\
\text { RISK that significant additional tax liabilities may arise. }\end{array}$ & Negative \\
\hline
\end{tabular}




\begin{tabular}{|c|c|c|}
\hline 74 & $\begin{array}{l}\text { Management estimates discount rates using pre-tax rates that reflect current market } \\
\text { assessments of the time value of money and the RISKs specific to the CGUs. }\end{array}$ & Negative \\
\hline 75 & $\begin{array}{l}\text { We are not required to consider whether the board's statements on internal control cover all } \\
\text { RISKs and controls, or form an opinion on the effectiveness of the group's corporate } \\
\text { governance procedures or its RISK and control procedures. }\end{array}$ & Negative \\
\hline 76 & The Group is exposed to foreign currency RISK on purchases denominated in US dollars. & Negative \\
\hline 77 & $\begin{array}{l}\text { The Group is not exposed to equity securities price RISK because no such investments are } \\
\text { held by the Group. }\end{array}$ & Negative \\
\hline 78 & $\begin{array}{l}\text { The Company's RISK management policies are established to identify and analyse the } \\
\text { RISKS faced by the Company, to set appropriate risk limits and controls, and to monitor } \\
\text { risks and adherence to limits. }\end{array}$ & Negative \\
\hline 79 & $\begin{array}{l}\text { Conversely, whilst floating rate borrowings are not exposed to changes in fair value, the } \\
\text { Group is exposed to cash flow interest rate RISK as costs are impacted by changes in market } \\
\text { rates. }\end{array}$ & Negative \\
\hline 80 & $\begin{array}{l}\text { Many of the International Power Projects contracts require sophisticated RISK management, } \\
\text { and the Group deploys a number of tools to manage its risk, including advanced payments, } \\
\text { letters of credit, bank guarantees, bonds, credit and political risk insurance. }\end{array}$ & Negative \\
\hline 81 & $\begin{array}{l}\text { The Group's credit RISK is primarily attributable to its trade and other Receivables. The } \\
\text { amounts presented in the balance sheet are net of allowances for doubtful receivables. }\end{array}$ & Negative \\
\hline 82 & $\begin{array}{l}\text { Foreign exchange RISK arises when future commercial transactions or recognised assets or } \\
\text { liabilities are denominated in a currency that is not the entity's functional currency. }\end{array}$ & Negative \\
\hline 83 & $\begin{array}{l}\text { Internal Audit's work is focused on areas of greatest RISK to EasyJet, as determined by } \\
\text { managements' risk identification and assessment processes as validated by Executive } \\
\text { Directors. }\end{array}$ & Negative \\
\hline 84 & $\begin{array}{l}\text { We manage the commercial and operational RISKS faced by the group in accordance with } \\
\text { policies approved by the board. }\end{array}$ & Negative \\
\hline 85 & $\begin{array}{l}\text { As a result of the global economic downturn, management has taken a number of steps to } \\
\text { protect the Group against defaulting customers, by amending sales contracts to provide for } \\
\text { advance payment and delaying the transfer of title to goods sold, by obtaining parent } \\
\text { company guarantees and implementing RISK profiling of key and new customers. }\end{array}$ & Negative \\
\hline 86 & $\begin{array}{l}\text { These controls are managed by the use of formal procedures designed to highlight financial, } \\
\text { operational, environmental and social RISKs and provide appropriate information to the } \\
\text { Board enabling it to protect effectively the Company's assets and, in turn, maintain } \\
\text { shareholder value. }\end{array}$ & Negative \\
\hline 87 & The Group is exposed to commodity price RISK in its LPG and oil distribution businesses. & Negative \\
\hline 88 & $\begin{array}{l}\text { Our products, when properly used, present negligible health RISKs and, where appropriate, } \\
\text { Materials Safety Data Sheets advising on optimal application procedures, are available to our } \\
\text { customers. }\end{array}$ & Negative \\
\hline 89 & $\begin{array}{l}\text { We are well aware that buying businesses can be RISKy, and that statistics show that many } \\
\text { of them are value-destructive. }\end{array}$ & Negative \\
\hline 90 & $\begin{array}{l}\text { In light of the current global economic downturn, steps have been taken in order to assess } \\
\text { and monitor any potential impact on AMEC's project opportunities and address potential } \\
\text { increased supply chain RISK. }\end{array}$ & Negative \\
\hline \multicolumn{3}{|c|}{ Panel (B): Mixed and Unclear Sentences } \\
\hline 91 & $\begin{array}{l}\text { We believe this approach makes sound business sense as well as being crucial for RISK and } \\
\text { opportunity management. }\end{array}$ & $\begin{array}{l}\text { Negative } \\
\& \text { Positive }\end{array}$ \\
\hline 92 & $\begin{array}{l}\text { We also recognise that the effective management of social, environmental and ethical issues } \\
\text { can help us to identify and manage RISKs and develop new commercial opportunities. }\end{array}$ & $\begin{array}{l}\text { Negative } \\
\& \text { Positive }\end{array}$ \\
\hline 93 & $\begin{array}{l}\text { We continue to assess the RISK profile of opportunities and carefully select the type of } \\
\text { contracts and clients. }\end{array}$ & $\begin{array}{l}\text { Negative } \\
\& \text { Positive }\end{array}$ \\
\hline 94 & $\begin{array}{l}\text { The attainment of Level } 3 \text { in the implementation of the DNV management information } \\
\text { system which provides a framework to improve occupational health and safety performance, } \\
\text { including RISK and opportunity identification, analysis, target setting, and measurement }\end{array}$ & $\begin{array}{l}\text { Negative } \\
\& \text { Positive }\end{array}$ \\
\hline 95 & $\begin{array}{l}\text { This section describes the principal RISKs and uncertainties which may affect EasyJet's } \\
\text { business, financial results and prospects. }\end{array}$ & $\begin{array}{l}\text { Negative } \\
\& \text { Positive }\end{array}$ \\
\hline 96 & $\begin{array}{l}\text { The board's policies are implemented by dedicated specialists who make sure effective } \\
\text { processes and procedures are in place to assure compliance and to identify and to report on } \\
\text { RISKs and opportunities. }\end{array}$ & $\begin{array}{l}\text { Negative } \\
\& \text { Positive }\end{array}$ \\
\hline
\end{tabular}


97

98

99

All of the Directors bring independent judgment to bear on issues of strategy, RISK, performance, resources, key appointments and standards.

In addition, the Audit Committee, on behalf of the Board, has conducted a specific annual review of the effectiveness of the Group's system of internal controls and RISK management.

A mechanism exists to extend the Group's formal RISK management processes to any significant new business acquired or begun by the Company immediately upon acquisition or start-up.

RISK management policies have been set by the Board and applied by the Group.

Table (2): The Negative and Positive Keywords Frequency

\begin{tabular}{|c|c|c|c|}
\hline Risk as a Gain & Frequency & Risk as a Loss & Frequency \\
\hline Gain & 95 & Loss & 378 \\
\hline Potential & 151 & Exposure & 1,044 \\
\hline Opportunity & 83 & Uncertain & 451 \\
\hline Prospect & 23 & Against & 263 \\
\hline Advantage & 5 & Failure & 224 \\
\hline Viable & 4 & Hazard & 42 \\
\hline Upside & 2 & Threat & 10 \\
\hline Peak & 1 & Catastrophe & 11 \\
\hline Chance & 0 & Harm & 9 \\
\hline Surprise & 0 & Contingency & 8 \\
\hline Total & $\mathbf{3 6 4}(\mathbf{1 3 \%})$ & Total & $\mathbf{2 , 4 4 0}(\mathbf{8 7 \%})$ \\
\hline & & Unable & 4 \\
\hline & & Danger & 3 \\
\hline & & Shock & 3 \\
\hline & & Shortage & 2 \\
\hline & & Total & $\mathbf{2 , 4 5 2}$ \\
\hline
\end{tabular}




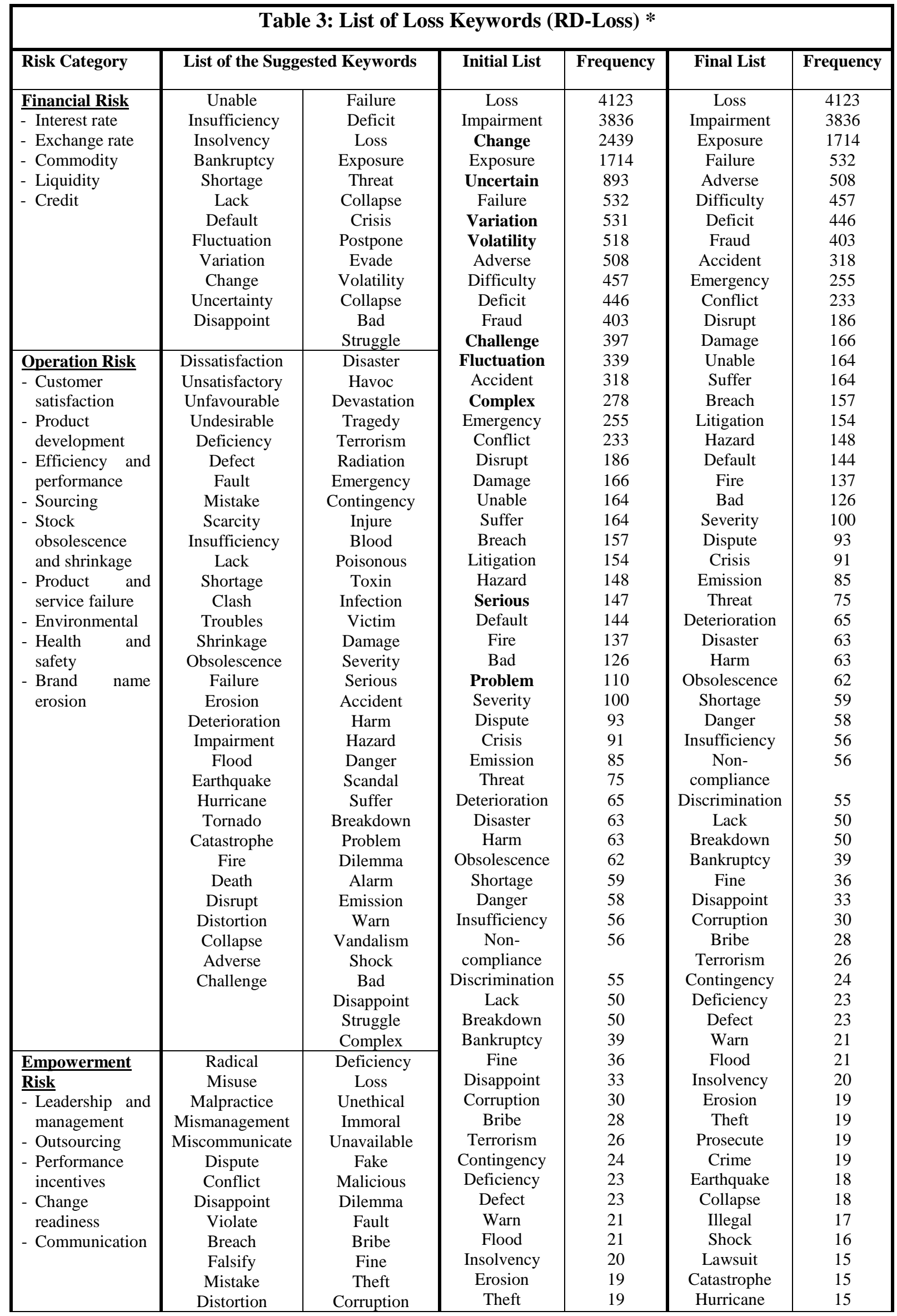




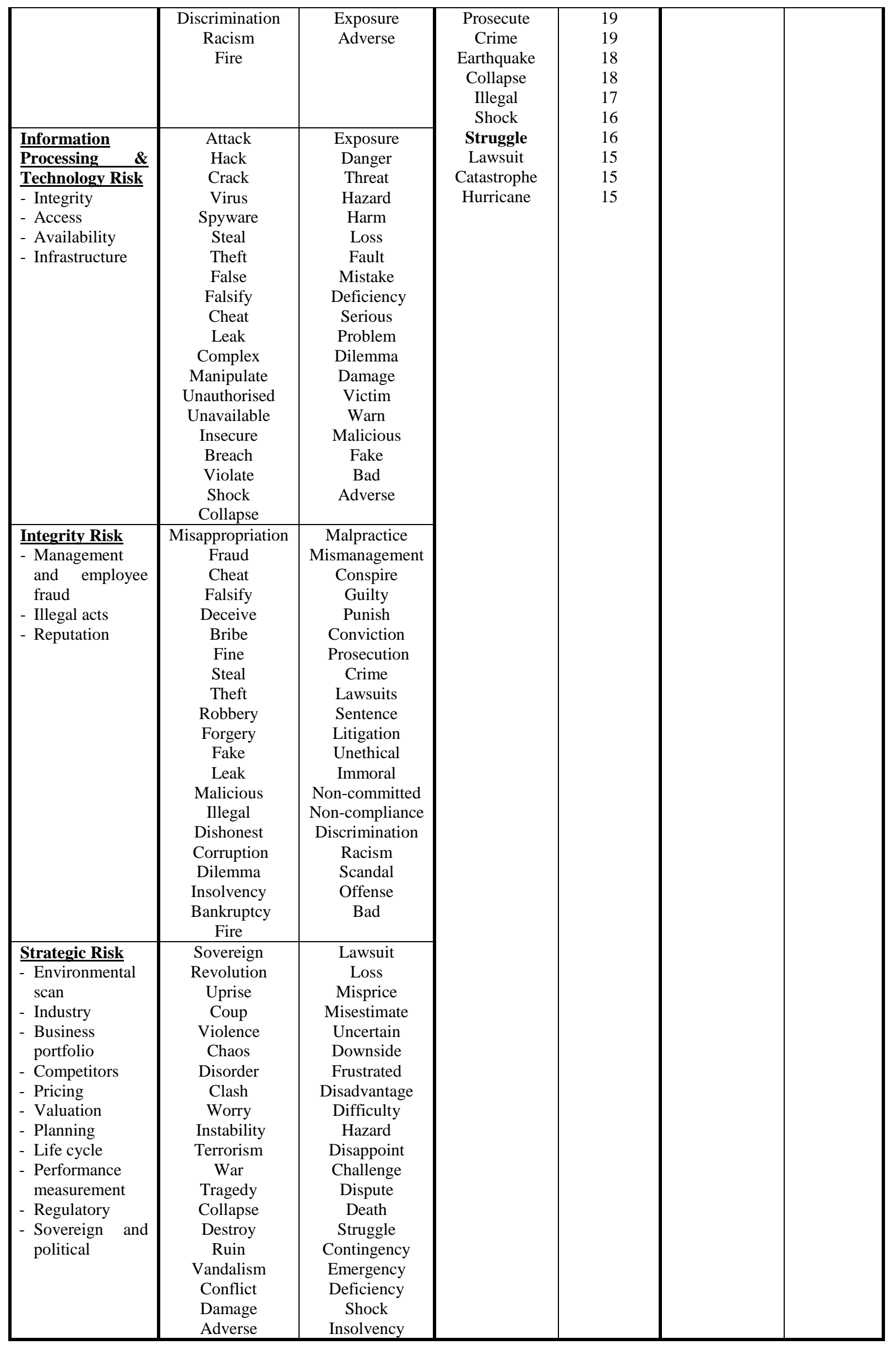


*Table (3) exhibits six risk categories, a list of 153 suggested keywords, an initial list of 70 keywords, and a final list of 60 keywords.

Table 4: The Selected Positive Keywords

\begin{tabular}{|c|c|c|c|c|c|c|c|}
\hline & $\begin{array}{c}\text { List of } \\
\text { Suggested }\end{array}$ & & Freouency & & Freauency & \multicolumn{2}{|c|}{$\begin{array}{c}\text { Final Positive \& } \\
\text { Negative List }\end{array}$} \\
\hline $\begin{array}{l}\text { Linsley \& } \\
\text { Shrives } \\
\text { (2006a) }\end{array}$ & $\begin{array}{l}\text { Opportunity } \\
\text { Prospect }\end{array}$ & $\begin{array}{c}\text { Gain } \\
\text { Achievement } \\
\text { Opportunity }\end{array}$ & $\begin{array}{l}3115 \\
2552 \\
1973\end{array}$ & $\begin{array}{c}\text { Gain } \\
\text { Achievement } \\
\text { Opportunity }\end{array}$ & $\begin{array}{l}3115 \\
2552 \\
1973\end{array}$ & $\begin{array}{c}\text { Positive } \\
\text { Keywords }\end{array}$ & $\begin{array}{c}\text { Fire } \\
\text { Bad } \\
\text { Severity }\end{array}$ \\
\hline $\begin{array}{l}\text { Abraham \& } \\
\text { Cox (2007) }\end{array}$ & $\begin{array}{c}\text { Opportunity } \\
\text { Prospect } \\
\text { Potential } \\
\text { Upside } \\
\text { Advantage }\end{array}$ & $\begin{array}{c}\text { Success } \\
\text { Potential } \\
\text { Outstanding } \\
\text { Agree } \\
\text { Possible }\end{array}$ & $\begin{array}{c}1715 \\
1651 \\
1592 \\
1232 \\
875\end{array}$ & $\begin{array}{l}\text { Success } \\
\text { Potential } \\
\text { Excellent } \\
\text { Prospect } \\
\text { Advantage }\end{array}$ & $\begin{array}{c}1715 \\
1651 \\
777 \\
571 \\
507\end{array}$ & $\begin{array}{c}\text { Gain } \\
\text { Achievement } \\
\text { Opportunity } \\
\text { Success } \\
\text { Potential }\end{array}$ & \begin{tabular}{|c|} 
Dispute \\
Crisis \\
Emission \\
Threat \\
Deterioration
\end{tabular} \\
\hline $\begin{array}{c}\text { Elshandid } \\
\text { y (2011) } \\
\text { Elshandid } \\
\text { y et al. } \\
(2013 ; 2015) \\
\text { Elshandid } \\
\text { y \& Neri } \\
(2015)\end{array}$ & $\begin{array}{c}\text { Chance } \\
\text { Gain } \\
\text { Peak } \\
\text { Viability } \\
\text { Potential } \\
\text { Advantage } \\
\text { Upside }\end{array}$ & $\begin{array}{c}\text { Accept } \\
\text { Excellent } \\
\text { Prospect } \\
\text { Advantage } \\
\text { Surplus } \\
\text { Satisfactory } \\
\text { superior } \\
\text { Win } \\
\text { Chance } \\
\text { Peak } \\
\text { Viable } \\
\text { Remarkable }\end{array}$ & $\begin{array}{c}826 \\
777 \\
571 \\
507 \\
417 \\
381 \\
191 \\
136 \\
69 \\
59 \\
56 \\
18\end{array}$ & $\begin{array}{c}\text { Surplus } \\
\text { Satisfactory } \\
\text { Superior } \\
\text { Win } \\
\text { Chance } \\
\text { Remarkable } \\
\text { Accomplish }\end{array}$ & $\begin{array}{l}417 \\
381 \\
191 \\
136 \\
69 \\
18 \\
16\end{array}$ & $\begin{array}{c}\text { Excellent } \\
\text { Prospect } \\
\text { Advantage } \\
\text { Surplus } \\
\text { Satisfactory } \\
\text { Superior } \\
\text { Win } \\
\text { Chance } \\
\text { Remarkable } \\
\text { Accomplish } \\
\text { Negative }\end{array}$ & \begin{tabular}{|} 
Disaster \\
Harm \\
Obsolescence \\
Shortage \\
Danger \\
Insufficiency \\
Non-compliance \\
Discrimination \\
Lack \\
Breakdown \\
Bankruptcy \\
Fine
\end{tabular} \\
\hline $\begin{array}{c}\text { Suggested } \\
\text { Keywords } \\
\text { (Disctionary) }\end{array}$ & $\begin{array}{c}\text { Achievement } \\
\text { Accomplish } \\
\text { ment } \\
\text { Success } \\
\text { Outstanding } \\
\text { Remarkable } \\
\text { Wonderful } \\
\text { Excellent } \\
\text { Perfect } \\
\text { Satisfactory } \\
\text { Agree } \\
\text { Possible } \\
\text { Accept } \\
\text { Luck } \\
\text { Concord } \\
\text { Victory } \\
\text { Congruence } \\
\text { Win } \\
\text { Harmony } \\
\text { Favourable } \\
\text { Peacefully } \\
\text { Surplus } \\
\text { Superior }\end{array}$ & $\begin{array}{c}\text { Accomplish } \\
\text { Peacefully } \\
\text { Perfect } \\
\text { Upside } \\
\text { Wonderful } \\
\text { Harmony } \\
\text { Favorable } \\
\text { Luck } \\
\text { Concord } \\
\text { victory } \\
\text { Congruence }\end{array}$ & $\begin{array}{c}16 \\
14 \\
14 \\
14 \\
5 \\
4 \\
3 \\
2 \\
2 \\
1 \\
0\end{array}$ & & & $\begin{array}{c}\text { Keywords } \\
\text { Loss } \\
\text { Impairment } \\
\text { Exposure } \\
\text { Failure } \\
\text { Adverse } \\
\text { Difficulty } \\
\text { Deficit } \\
\text { Fraud } \\
\text { Accident } \\
\text { Emergency } \\
\text { Conflict } \\
\text { Disrupt } \\
\text { Damage } \\
\text { Unable } \\
\text { Suffer } \\
\text { Breach } \\
\text { Litigation } \\
\text { Hazard } \\
\text { Default }\end{array}$ & $\begin{array}{l}\text { Disappoint } \\
\text { Corruption } \\
\text { Bribe } \\
\text { Terrorism } \\
\text { Contingency } \\
\text { Deficiency } \\
\text { Defect } \\
\text { Warn } \\
\text { Flood } \\
\text { Insolvency } \\
\text { Erosion } \\
\text { Theft } \\
\text { Prosecute } \\
\text { Crime } \\
\text { Earthquake } \\
\text { Collapse } \\
\text { Illegal } \\
\text { Shock } \\
\text { Lawsuit } \\
\text { Catastrophe } \\
\text { Hurricane }\end{array}$ \\
\hline
\end{tabular}


Table 5: The Variation Keywords List (RD-Variation)

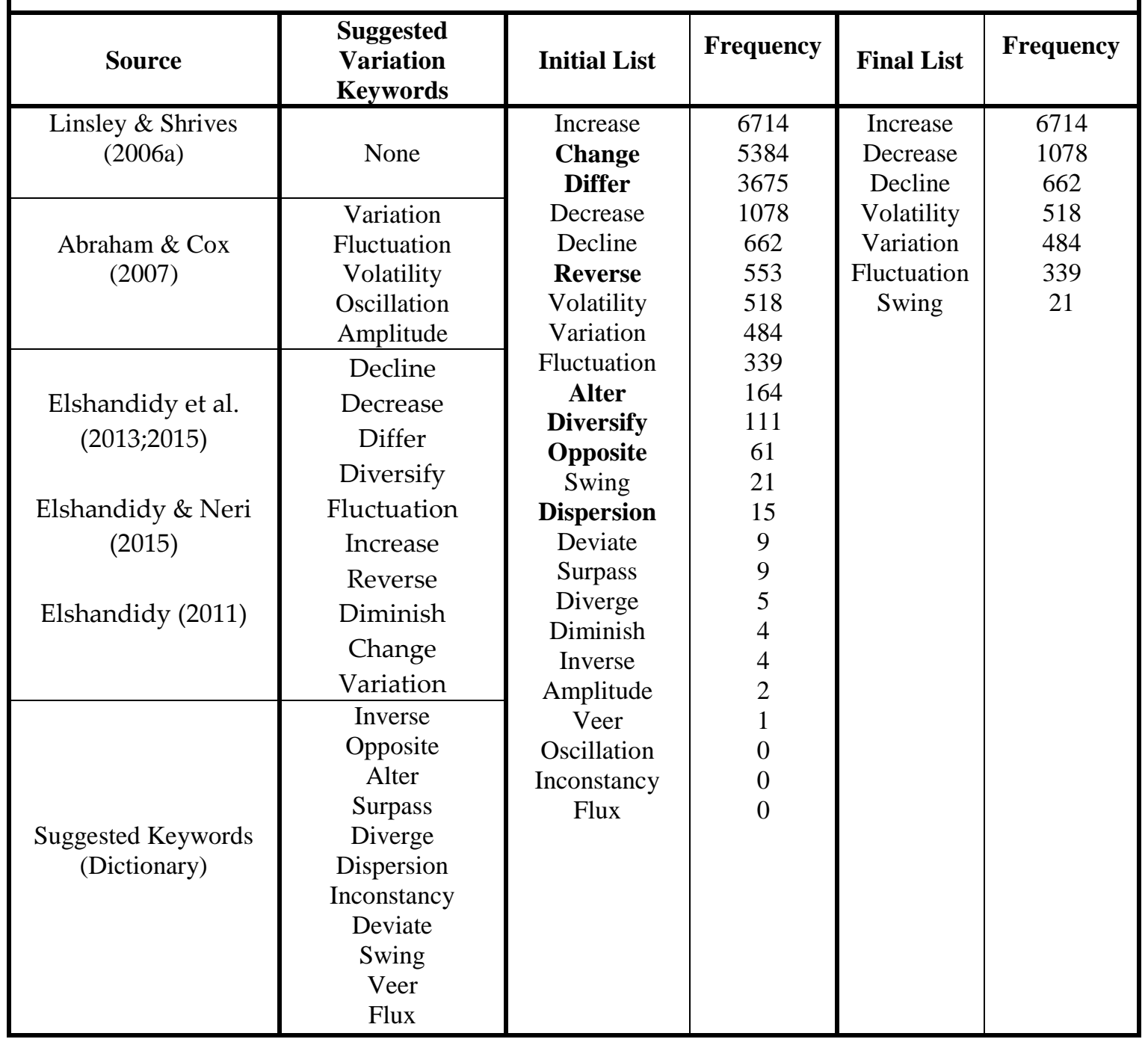


Table 6: Descriptive Statistics for the RD Score as total and across Years*

\begin{tabular}{|c|c|c|c|c|c|c|c|c|}
\hline & $\mathbf{N}$ & Min & Max & Mean & Median & Std. Dev & Skewness & Kurtosis \\
\hline \multicolumn{9}{|c|}{ Panel A: Descriptive Statistics for the RD-Loss Score } \\
\hline All Years & 2898 & 21 & 417 & 148 & 137 & 70.91 & 0.95 & 1.09 \\
\hline 2005 & 230 & 22 & 368 & 96 & 86 & 53.26 & 1.75 & 4.70 \\
\hline 2006 & 238 & 23 & 338 & 111 & 102 & 54.89 & 1.21 & 1.95 \\
\hline 2007 & 249 & 26 & 344 & 115 & 108 & 53.36 & 0.98 & 1.46 \\
\hline 2008 & 261 & 24 & 357 & 139 & 127 & 61.79 & 0.96 & 1.14 \\
\hline 2009 & 265 & 24 & 396 & 153 & 141 & 69.87 & 1.03 & 1.18 \\
\hline 2010 & 266 & 26 & 402 & 154 & 142 & 68.40 & 0.93 & 1.07 \\
\hline 2011 & 268 & 24 & 398 & 154 & 146 & 67.11 & 1.06 & 1.70 \\
\hline 2012 & 268 & 21 & 411 & 154 & 148 & 66.29 & 0.86 & 1.19 \\
\hline 2013 & 274 & 26 & 407 & 174 & 166 & 74.92 & 0.89 & 0.68 \\
\hline 2014 & 285 & 25 & 404 & 174 & 170 & 70.58 & 0.75 & 0.97 \\
\hline 2015 & 294 & 34 & 417 & 180 & 171 & 76.55 & 0.74 & 0.59 \\
\hline \multicolumn{9}{|c|}{ Panel B: Descriptive Statistics for the RD-LossGain Score } \\
\hline All Years & 2898 & 36 & 607 & 225 & 210 & 102.14 & 0.87 & 0.85 \\
\hline 2005 & 230 & 37 & 564 & 148 & 132 & 75.99 & 1.93 & 6.61 \\
\hline 2006 & 238 & 43 & 573 & 172 & 156 & 78.96 & 1.38 & 3.47 \\
\hline 2007 & 249 & 38 & 516 & 176 & 164 & 74.71 & 0.88 & 1.36 \\
\hline 2008 & 262 & 36 & 585 & 205 & 191 & 85.89 & 0.93 & 1.66 \\
\hline 2009 & 265 & 52 & 554 & 223 & 211 & 94.07 & 0.83 & 0.72 \\
\hline 2010 & 265 & 54 & 551 & 227 & 216 & 93.22 & 0.89 & 1.13 \\
\hline 2011 & 266 & 76 & 604 & 233 & 223 & 93.35 & 1.01 & 1.46 \\
\hline 2012 & 267 & 52 & 552 & 238 & 223 & 96.87 & 0.71 & 0.37 \\
\hline 2013 & 274 & 53 & 605 & 269 & 259 & 106.14 & 0.74 & 0.43 \\
\hline 2014 & 286 & 40 & 589 & 274 & 265 & 101.99 & 0.57 & 0.58 \\
\hline 2015 & 296 & 45 & 607 & 284 & 273 & 110.26 & 0.62 & 0.29 \\
\hline \multicolumn{9}{|c|}{ Panel C: Descriptive Statistics for the RD-Variation Score } \\
\hline All Years & 2898 & 8 & 320 & 85 & 76 & 46.51 & 1.39 & 2.78 \\
\hline 2005 & 230 & 8 & 267 & 59 & 51 & 37.10 & 2.15 & 6.76 \\
\hline 2006 & 237 & 13 & 301 & 70 & 61 & 41.63 & 2.21 & 6.91 \\
\hline 2007 & 249 & 9 & 266 & 69 & 61 & 40.09 & 2.10 & 6.29 \\
\hline 2008 & 260 & 8 & 280 & 78 & 70 & 43.75 & 1.67 & 3.92 \\
\hline 2009 & 265 & 13 & 320 & 84 & 74 & 50.96 & 1.90 & 4.97 \\
\hline 2010 & 264 & 10 & 291 & 85 & 77 & 44.41 & 1.53 & 3.42 \\
\hline 2011 & 265 & 11 & 284 & 87 & 79 & 44.33 & 1.49 & 3.48 \\
\hline 2012 & 267 & 8 & 311 & 89 & 83 & 46.14 & 1.30 & 3.15 \\
\hline 2013 & 273 & 8 & 288 & 99 & 90 & 47.69 & 0.90 & 1.03 \\
\hline 2014 & 288 & 10 & 290 & 101 & 94 & 44.93 & 1.09 & 2.12 \\
\hline 2015 & 300 & 20 & 279 & 102 & 97 & 47.00 & 0.87 & 1.03 \\
\hline \multicolumn{9}{|c|}{ Panel D: Descriptive Statistics for the RD-Comprehensive Score } \\
\hline All Years & 2898 & 52 & 977 & 356 & 328 & 163.69 & 0.91 & 0.92 \\
\hline 2005 & 228 & 52 & 898 & 227 & 209 & 116.14 & 1.97 & 6.65 \\
\hline 2006 & 238 & 65 & 760 & 268 & 250 & 122.03 & 1.35 & 2.60 \\
\hline 2007 & 251 & 53 & 814 & 280 & 252 & 125.81 & 1.29 & 2.78 \\
\hline 2008 & 262 & 54 & 878 & 320 & 300 & 137.94 & 1.10 & 1.97 \\
\hline 2009 & 265 & 80 & 947 & 347 & 317 & 153.05 & 1.08 & 1.64 \\
\hline 2010 & 265 & 96 & 907 & 357 & 334 & 150.89 & 1.03 & 1.48 \\
\hline 2011 & 266 & 117 & 970 & 368 & 351 & 149.90 & 1.06 & 1.58 \\
\hline 2012 & 268 & 54 & 888 & 375 & 359 & 155.56 & 0.71 & 0.52 \\
\hline 2013 & 272 & 73 & 919 & 423 & 403 & 165.09 & 0.70 & 0.41 \\
\hline 2014 & 287 & 71 & 977 & 439 & 423 & 161.33 & 0.69 & 0.90 \\
\hline 2015 & 297 & 83 & 966 & 456 & 436 & 173.97 & 0.58 & 0.30 \\
\hline
\end{tabular}

*Descriptive statistics were conducted after excluding 710 missing observation on RD out of a total of 3608 and after trimming top and bottom $1 \%$ of all the remaining RD-Scores, but before any data transformation. 


\begin{tabular}{|c|c|c|c|c|c|c|c|c|c|}
\hline \multicolumn{10}{|c|}{ Table 7: Descriptive Statistics for the RD Score across Industries* } \\
\hline & Industry & $\mathbf{N}$ & Min & Max & Mean & Median & $\begin{array}{l}\text { Std. } \\
\text { Dev }\end{array}$ & Skewness & Kurtosis \\
\hline \multicolumn{10}{|c|}{ Panel A: Descriptive Statistics for the RD-Loss Score } \\
\hline & All Industries & 2898 & 21 & 417 & 148 & 137 & 70.91 & 0.95 & 1.09 \\
\hline 1 & Consumer Goods & 339 & 28 & 407 & 147 & 135 & 75.00 & 0.82 & 0.50 \\
\hline 2 & Oil \& Gas & 138 & 22 & 415 & 154 & 148 & 74.49 & 0.85 & 1.19 \\
\hline 3 & Consumer Services & 734 & 23 & 322 & 134 & 128 & 58.05 & 0.38 & -0.46 \\
\hline 4 & Industrials & 1083 & 21 & 393 & 144 & 138 & 59.78 & 0.85 & 1.29 \\
\hline 5 & Healthcare & 119 & 50 & 417 & 175 & 151 & 94.42 & 0.98 & -0.07 \\
\hline 6 & Basic Materials & 244 & 26 & 411 & 193 & 189 & 95.20 & 0.38 & -0.65 \\
\hline 7 & Telecommunications & 55 & 27 & 326 & 133 & 113 & 74.63 & 1.01 & 0.24 \\
\hline 8 & Utilities & 62 & 46 & 404 & 212 & 199 & 94.76 & 0.17 & -0.83 \\
\hline 9 & Technology & 124 & 24 & 270 & 109 & 106 & 46.33 & 0.53 & 0.26 \\
\hline \multicolumn{10}{|c|}{ Panel B: Descriptive Statistics for the RD-LossGain Score } \\
\hline \multicolumn{2}{|c|}{ All Industries } & 2898 & 36 & 607 & 225 & 210 & 102.14 & 0.87 & 0.85 \\
\hline 1 & Consumer Goods & 339 & 46 & 570 & 225 & 204 & 104.74 & 0.78 & 0.29 \\
\hline 2 & Oil \& Gas & 138 & 46 & 583 & 254 & 249 & 114.91 & 0.56 & 0.07 \\
\hline 3 & Consumer Services & 730 & 39 & 573 & 208 & 200 & 88.19 & 0.54 & 0.51 \\
\hline 4 & Industrials & 1083 & 38 & 607 & 220 & 208 & 90.40 & 0.90 & 1.35 \\
\hline 5 & Healthcare & 118 & 63 & 586 & 264 & 239 & 119.33 & 0.89 & 0.20 \\
\hline 6 & Basic Materials & 248 & 38 & 605 & 276 & 269 & 132.86 & 0.42 & -0.63 \\
\hline 7 & Telecommunications & 55 & 37 & 429 & 207 & 186 & 101.35 & 0.66 & -0.47 \\
\hline 8 & Utilities & 63 & 53 & 585 & 311 & 285 & 131.52 & 0.25 & -0.75 \\
\hline 9 & Technology & 124 & 36 & 366 & 174 & 169 & 67.15 & 0.43 & 0.12 \\
\hline \multicolumn{10}{|c|}{ Panel C: Descriptive Statistics for the RD-Variation Score } \\
\hline \multicolumn{2}{|c|}{ All Industries } & 2898 & 8 & 320 & 85 & 76 & 46.51 & 1.39 & 2.78 \\
\hline 1 & Consumer Goods & 334 & 10 & 247 & 86 & 81 & 43.24 & 0.91 & 1.04 \\
\hline 2 & Oil \& Gas & 135 & 9 & 223 & 82 & 74 & 45.67 & 1.15 & 1.45 \\
\hline 3 & Consumer Services & 736 & 8 & 254 & 77 & 75 & 35.91 & 0.77 & 1.20 \\
\hline 4 & Industrials & 1087 & 8 & 236 & 78 & 73 & 35.90 & 0.79 & 0.73 \\
\hline 5 & Healthcare & 127 & 9 & 301 & 114 & 94 & 74.79 & 0.86 & -0.21 \\
\hline 6 & Basic Materials & 240 & 9 & 320 & 120 & 107 & 67.07 & 0.71 & -0.17 \\
\hline 7 & Telecommunications & 55 & 10 & 273 & 108 & 73 & 74.94 & 0.83 & -0.68 \\
\hline 8 & Utilities & 62 & 17 & 303 & 119 & 106 & 59.45 & 0.82 & 0.55 \\
\hline 9 & Technology & 122 & 12 & 159 & 67 & 66 & 26.47 & 0.74 & 1.34 \\
\hline \multicolumn{10}{|c|}{ Panel D: Descriptive Statistics for the RD-Comprehensive Score } \\
\hline & 1 Industries & 2898 & 52 & 977 & 356 & 328 & 163.69 & 0.91 & 0.92 \\
\hline 1 & Consumer Goods & 341 & 80 & 970 & 364 & 333 & 175.77 & 1.02 & 1.08 \\
\hline 2 & Oil \& Gas & 138 & 53 & 893 & 395 & 377 & 182.49 & 0.52 & -0.13 \\
\hline 3 & Consumer Services & 734 & 58 & 820 & 327 & 316 & 139.10 & 0.53 & 0.24 \\
\hline 4 & Industrials & 1082 & 54 & 977 & 341 & 324 & 138.40 & 0.78 & 0.97 \\
\hline 5 & Healthcare & 120 & 91 & 923 & 426 & 377 & 204.17 & 0.75 & -0.22 \\
\hline 6 & Basic Materials & 243 & 53 & 954 & 445 & 426 & 213.40 & 0.38 & -0.78 \\
\hline 7 & Telecommunications & 55 & 52 & 859 & 359 & 297 & 198.34 & 0.88 & -0.12 \\
\hline 8 & Utilities & 62 & 72 & 966 & 486 & 459 & 212.20 & 0.39 & -0.51 \\
\hline 9 & Technology & 124 & 54 & 581 & 276 & 274 & 106.36 & 0.41 & 0.29 \\
\hline
\end{tabular}

*Descriptive statistics were conducted after excluding 710 missing observation on RD out of a total of 3608 and after trimming top and bottom $1 \%$ of all the remaining RD-Scores, but before any data transformation. 